\title{
Trends in Nutrient and Soil Loss in Illinois Rivers, 1978-2017
}

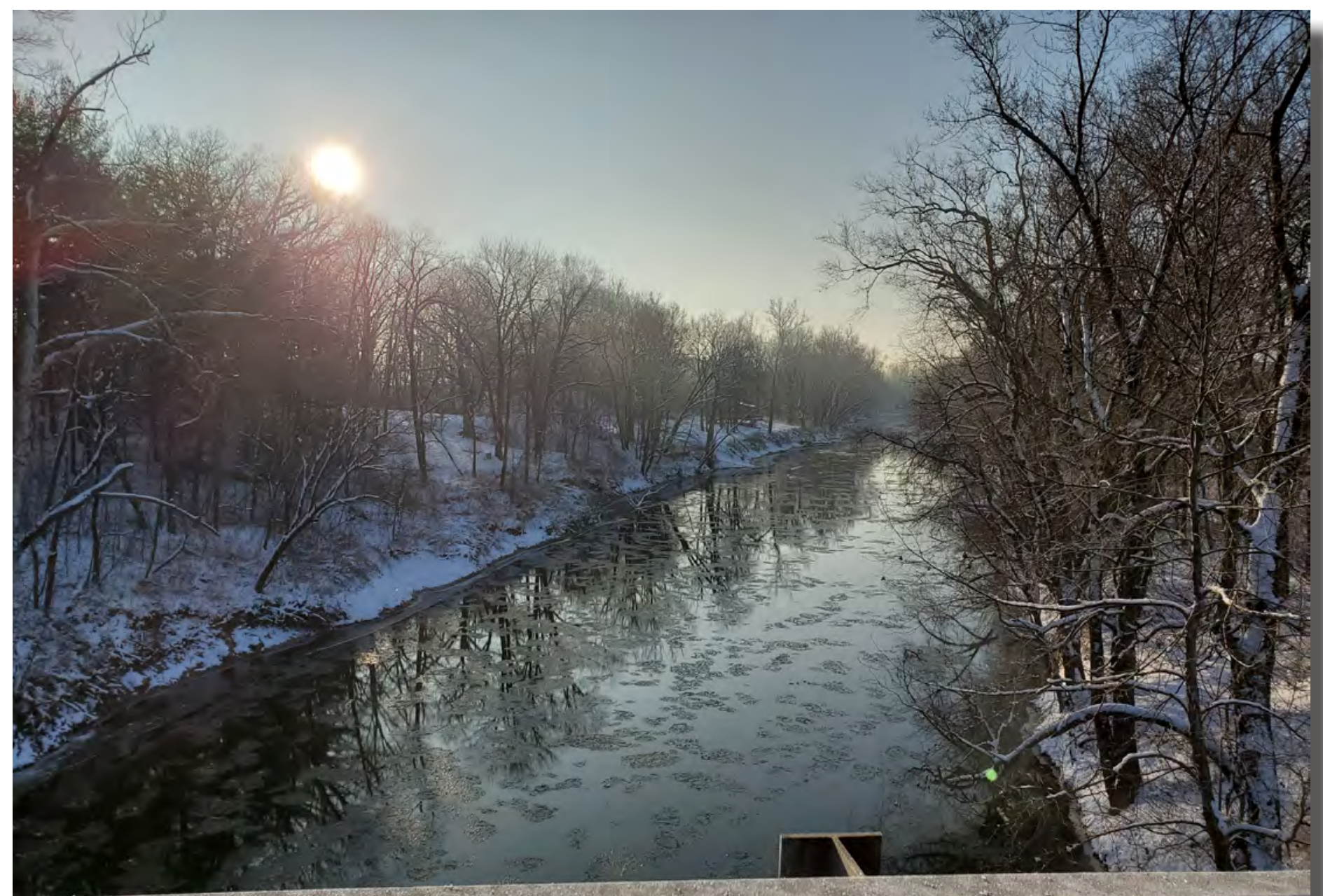

Scientific Investigations Report 2020-5041 
Cover photo. Winter sunrise over the Embarras River (03344000) near Fox Ridge State Park, Illinois (Photograph by Rebecca Meerdink). 


\title{
Trends in Nutrient and Soil Loss in Illinois Rivers, 1978-2017
}

\author{
By Timothy 0. Hodson and Paul J. Terrio
}

Scientific Investigations Report 2020-5041 


\title{
U.S. Department of the Interior \\ DAVID BERNHARDT, Secretary
}

\author{
U.S. Geological Survey \\ James F. Reilly II, Director
}

U.S. Geological Survey, Reston, Virginia: 2020

For more information on the USGS - the Federal source for science about the Earth, its natural and living resources, natural hazards, and the environment—visit https://www.usgs.gov or call 1-888-ASK-USGS.

For an overview of USGS information products, including maps, imagery, and publications, visit https://store.usgs.gov/.

Any use of trade, firm, or product names is for descriptive purposes only and does not imply endorsement by the U.S. Government.

Although this information product, for the most part, is in the public domain, it also may contain copyrighted materials as noted in the text. Permission to reproduce copyrighted items must be secured from the copyright owner.

Suggested citation:

Hodson, T.O., and Terrio, P.J., 2020, Trends in nutrient and soil loss in Illinois rivers, 1978-2017: U.S. Geological

Survey Scientific Investigations Report 2020-5041, 26 p., https://doi.org/10.3133/sir20205041.

ISSN 2328-0328 (online) 


\section{Acknowledgments}

This report would not have been possible without the committed efforts of the personnel at the Illinois Environmental Protection Agency, U.S. Geological Survey, and the IIlinois State Water Survey who collected and processed tens of thousands of water samples as part of the Ambient Water Quality Monitoring Network program. The authors also thank Gregg Good, Roy Smogor, Matt Short, Trevor Sample, and Missy Cain (all Illinois Environmental Protection Agency) for their assistance in compiling Ambient Water Quality Monitoring Network data and for providing their insights into its interpretation. 



\section{Contents}

Acknowledgments ……...................................................................................................................

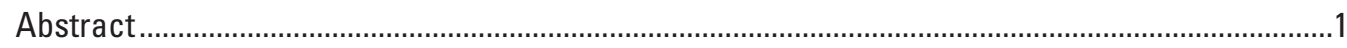

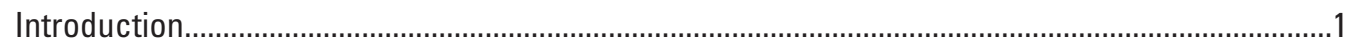

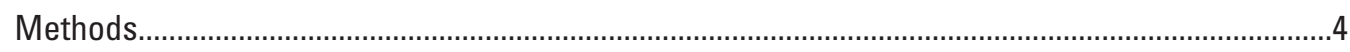

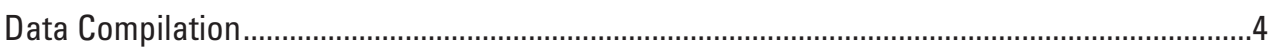

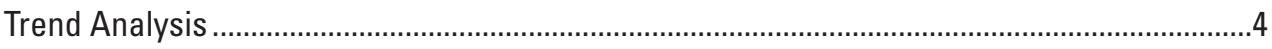

Trends in Nutrient and Soil Loss in Illinois Rivers, 1978-2017 .....................................................

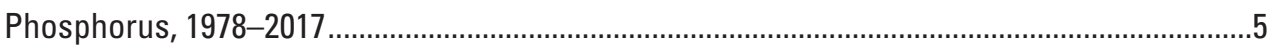

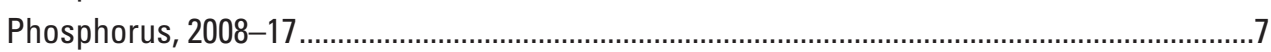

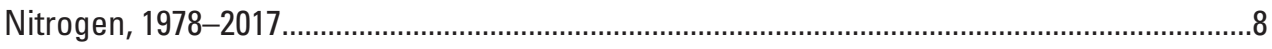

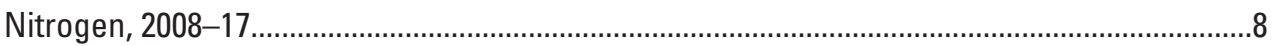

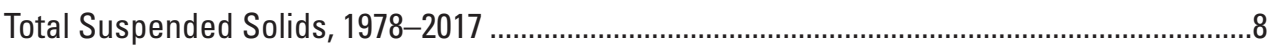

Total Suspended Solids, 2008-17 ...............................................................................................

Synopsis and Implications of Trends in Nutrient and Soil Loss …...............................................

Trends during 1978-2017....................................................................................................

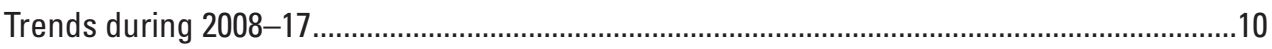

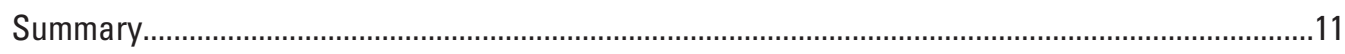

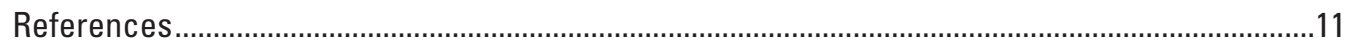

Appendix 1 Ambient Water Quality Monitoring Network Monitoring Site Information................15

Appendix 2 Supplementary Figures ....................................................................................

\section{Figures}

1. Map showing locations of Ambient Water Quality Monitoring Network water-quality monitoring sites........................................................................................

2. Maps of changes in flow-normalized concentration, flux, and yield of total phosphorus, total nitrogen, and total suspended solids .................................................

3. Boxplots showing statewide change in nutrient and total suspended solids fluxes for each trend component......................................................................................

4. Maps showing change in corn and soybean area and production, as well as population change, among counties in Illinois, 1978-2017.

\section{Tables}

1. Major river basins in Illinois, their farthest downstream Ambient Water Quality Monitoring Network identification, and the corresponding U.S. Geological Survey streamgage station number .

2. Change in flow-normalized yield for each major river basin ............................................. 


\section{Conversion Factors}

International System of Units to U.S. customary units

\begin{tabular}{lcl}
\hline & Multiply & \multicolumn{1}{c}{ To obtain } \\
\hline \multicolumn{3}{c}{ Area } \\
\hline square kilometer $\left(\mathrm{km}^{2}\right)$ & 247.1 & acre \\
\hline gigagram $(\mathrm{Gg})$ & Mass \\
kilogram $(\mathrm{kg})$ & 1,000 & metric ton $(\mathrm{t})$ \\
metric ton $(\mathrm{t})$ & 2.205 & pound avoirdupois $(\mathrm{lb})$ \\
metric ton $(\mathrm{t})$ & 1.102 & ton, short $[2,000 \mathrm{lb}]$ \\
& 0.9842 & ton, long $[2,240 \mathrm{lb}]$ \\
\hline \multicolumn{4}{c}{ Application rate } \\
\hline kilogram per hectare per year $([\mathrm{kg} / \mathrm{ha}] / \mathrm{yr})$ & 0.8921 & pound per acre per year $([\mathrm{lb} / \mathrm{acre}] / \mathrm{yr})$ \\
\hline
\end{tabular}

\section{Abbreviations}

$\begin{array}{ll}\text { AWOMN } & \text { Ambient Water Quality Monitoring Network } \\ \text { BBS } & \text { block bootstrap } \\ \text { CI } & \text { confidence interval } \\ \text { CQTC } & \text { concentration-discharge trend component } \\ \text { CRP } & \text { Conservation Reserve Program } \\ \text { CSP } & \text { Conservation Security Program } \\ \text { CWA } & \text { Clean Water Act } \\ \text { DP } & \text { dissolved phosphorus } \\ \text { EPA } & \text { U.S. Environmental Protection Agency } \\ \text { FN } & \text { flow normalized } \\ \text { HUC } & \text { hydrologic unit code } \\ \text { NO23 } & \text { nitrate and nitrite } \\ \text { PP } & \text { particulate phosphorus } \\ \text { OTC } & \text { streamflow trend component } \\ \text { TKN } & \text { total Kjeldahl nitrogen } \\ \text { TN } & \text { total nitrogen } \\ \text { TP } & \text { total phosphorus } \\ \text { TSS } & \text { total suspended solids } \\ \text { USGS } & \text { U.S. Geological Survey } \\ \end{array}$




\title{
Trends in Nutrient and Soil Loss in Illinois Rivers, 1978-2017
}

\author{
By Timothy 0. Hodson and Paul J. Terrio
}

\section{Abstract}

Nutrient and soil loss, defined herein as the loss of nutrients or soil to streams and other downstream receiving waters, affect watersheds around the globe. Although governments make large investments mitigating nutrient and soil loss through watershed management efforts, the efficacy of these efforts is often difficult to assess, in part because streamflow variability obscures the effects.

This study investigates the effects of watershed management on nutrient and soil losses in the State of Illinois during two periods: 1978 to 2017, and 2008 to 2017. The former period provides an important test case for assessing the efficacy of major Federal programs like the Clean Water Act and the Conservation Reserve Program at mitigating nutrient and soil loss, whereas the latter spans the years after these policies were well established, thereby providing an assessment of whether these programs have kept pace with ongoing trends in climate and watershed management.

The effect of interannual streamflow variability on long-term nutrient and soil loss trends was removed using an extension of the Weighted Regressions on Time, Discharge, and Season methodology, called generalized flow normalization. This process also partitions trends into components attributable to long-term changes in streamflow and watershed management. The Weighted Regressions on Time, Discharge, and Season trend analysis indicated significant, widespread trends in nutrient and soil loss in Illinois since 1978. From 1978 to 2017, improvements in watershed management reduced nitrogen and soil loss from watersheds within Illinois, but this effect was partially or entirely negated by increasing losses due to changing streamflow. During the same period, phosphorus loss also increased owing to a combination of inadequate management efforts and changing streamflow. During 2008-17, however, nutrient and soil losses have all accelerated, threatening to undo previous reductions if the current trends continue.

\section{Introduction}

Global population is projected to reach 9.8 billion by 2050 (United Nations, 2017). To feed this population, global agricultural production will need to increase by at least 50 percent (Alexandratos and Bruinsma, 2012). The cost to society and the environment of such a dramatic increase is far from certain, though it would be analogous, at least in rate, to global trends in agricultural production during the late 20th century (Fuglie, 2010).

Increasing agricultural production is associated with a variety of detrimental effects including habitat loss, increased greenhouse-gas emissions, soil erosion, and nutrient pollution - defined as excess amounts of nitrogen and phosphorus in aquatic systems (Brink and others, 1977; Galloway and others, 2003; Montgomery, 2007; Reay and others, 2012). Economic losses from soil erosion and nutrient pollution already exceed tens of billions of dollars per year in the United States and potentially hundreds of billions more worldwide (Borrelli and others, 2017; Dodds and others, 2009; Eswaran and others, 2001; Noone and others, 2012). Although soil and nutrient losses increase agricultural production costs, these "on-site" costs are minor compared to the "off-site" damages incurred when nutrients applied as fertilizers and sediment generated by soil erosion enter rivers, lakes, and other surface waters. In addition to fertilizer, other sources of nutrients in surface waters include human and animal waste, domestic and industrial wastewater, atmospheric deposition, and soil erosion (Dubrovsky and others, 2010). When nutrients from these and other sources enter surface waters, they can cause a variety of impairments in aquatic ecosystems including oxygen depletion and toxic algal blooms, which are lethal to aquatic fauna and make water unsafe for human consumption (Dodds and others, 2009; Heisler and others, 2008). Off-site damages associated with soil erosion result from higher than normal sediment loads, which disrupt and alter aquatic ecosystems and damage critical flood-control, transportation, and drinking-water infrastructure (Hauer and others, 2018). 
In the United States, public and private entities invest billions of dollars per year toward reducing nutrient pollution and soil erosion (U.S. Environmental Protection Agency [EPA], 2010); however, assessing the efficacy of these efforts is difficult. Multiple factors can cause changes in water quality including population growth, short- and long-term variability in streamflow, land-use change, and climate change. Also, temporal lags among implementation of a policy or management practice, its widespread adoption within a watershed, and its ultimate outcome can obfuscate the effects of policy and management efforts (Meals and others, 2010).

Surface-water-quality monitoring networks-networks of sites, often spread over large geographic areas, at which surface-water quality is periodically measured - enable accurate assessment of changes in surface-water quality through time. These networks are particularly effective when paired with continuous measurements of streamflow. In these cases, the effects of natural variability in streamflow can be removed, thereby isolating changes in water quality caused by human activity. The scale and scope of most water-quality monitoring networks in the United States have fluctuated through time. As a result, relatively few networks capture the overall effect of the landmark policies enacted to reduce water pollution and conserve soil that began in the 1970s and 1980s (Myers and Ludtke, 2017). These policies include the Clean Water Act (CWA), enacted in 1972; the Conservation Reserve Program (CRP), enacted in 1985; and the Conservation Security Program (CSP), enacted in 2002 but later replaced with the Conservation Stewardship Program. In brief, the CWA regulates point-source discharges of pollutants and funds construction of wastewater treatment plants, the CRP pays farmers to take vulnerable agricultural land out of production, and the CSP pays farmers to adopt conservation practices on land under production.

The State of Illinois has one of the longest-running and spatially dense surface-water-quality monitoring networks in the United States (fig. 1). Using water-quality data from the Illinois network, this study examines trends in nutrient (nitrogen and phosphorous) and total suspended solids (TSS) concentration and flux in Illinois rivers during two periods: 1978-2017 and 2008-17. The period from 1978 to 2017 spans the growth of the CWA, CRP, and CSP, and therefore provides an opportunity to assess the overall efficacy of these programs since their inception, or shortly thereafter in the case of the CWA. By 2008 to 2017, these policies were already well established and, therefore, changes during this period provide an indication of whether these policies are keeping pace with the effects of changes in land use and climate on soil and nutrient loss. Illinois represents an important test case of these policies because its landscape has been extensively modified by human activity, including dense urban areas, and some of the most productive agricultural land in the United States (U.S. Department of Agriculture, 2019). Measuring the effectiveness of any individual policy is exceedingly challenging, so this study takes a broader approach by attempting to assess their cumulative effectiveness at attenuating soil and nutrient losses.

In addition to providing a test case of the effectiveness of major environmental policies, these data are critical for anticipating future water-quality challenges in Illinois and abroad. Illinois is a leading producer of corn (Zea mays) and soybeans (Glycine max) in the United States, and its agricultural production has continued to increase through recent decades, in part due to rising demand for cornand soybean-based ethanol (EPA, 2018; Wallander and others, 2011). Consequently, Illinois is also one of the largest contributors of nitrogen and phosphorus to the Mississippi-Atchafalaya River Basin (Robertson and others, 2014), which contributes to widespread hypoxia in the Gulf of Mexico (Committee on Environmental and Natural Resources, 2000). Illinois, along with the other States within the Mississippi-Atchafalaya River Basin, has committed to reducing the amount of nitrogen and phosphorus flowing to the Gulf of Mexico by 45 percent, including an interim target reduction of 20 percent by 2025 (Mississippi River/Gulf of Mexico Watershed Nutrient Task Force, 2015), but whether progress is being made toward these targets remains unclear.

Although long-term nutrient trends have been studied at a handful of sites in Illinois (Markus and others, 2014; McIsaac and others, 2016; Murphy and others, 2013; Oelsner and others, 2017), these studies either included few monitoring sites, lacked confidence intervals surrounding trend estimates, or made no differentiation between the effects of changes in watershed management as compared to the effects of changes in streamflow. This report uses improved statistical methods, along with data from a larger monitoring network, to remedy those shortcomings and to provide an assessment of trends in nutrient and soil loss in Illinois rivers during 1978-2017. 


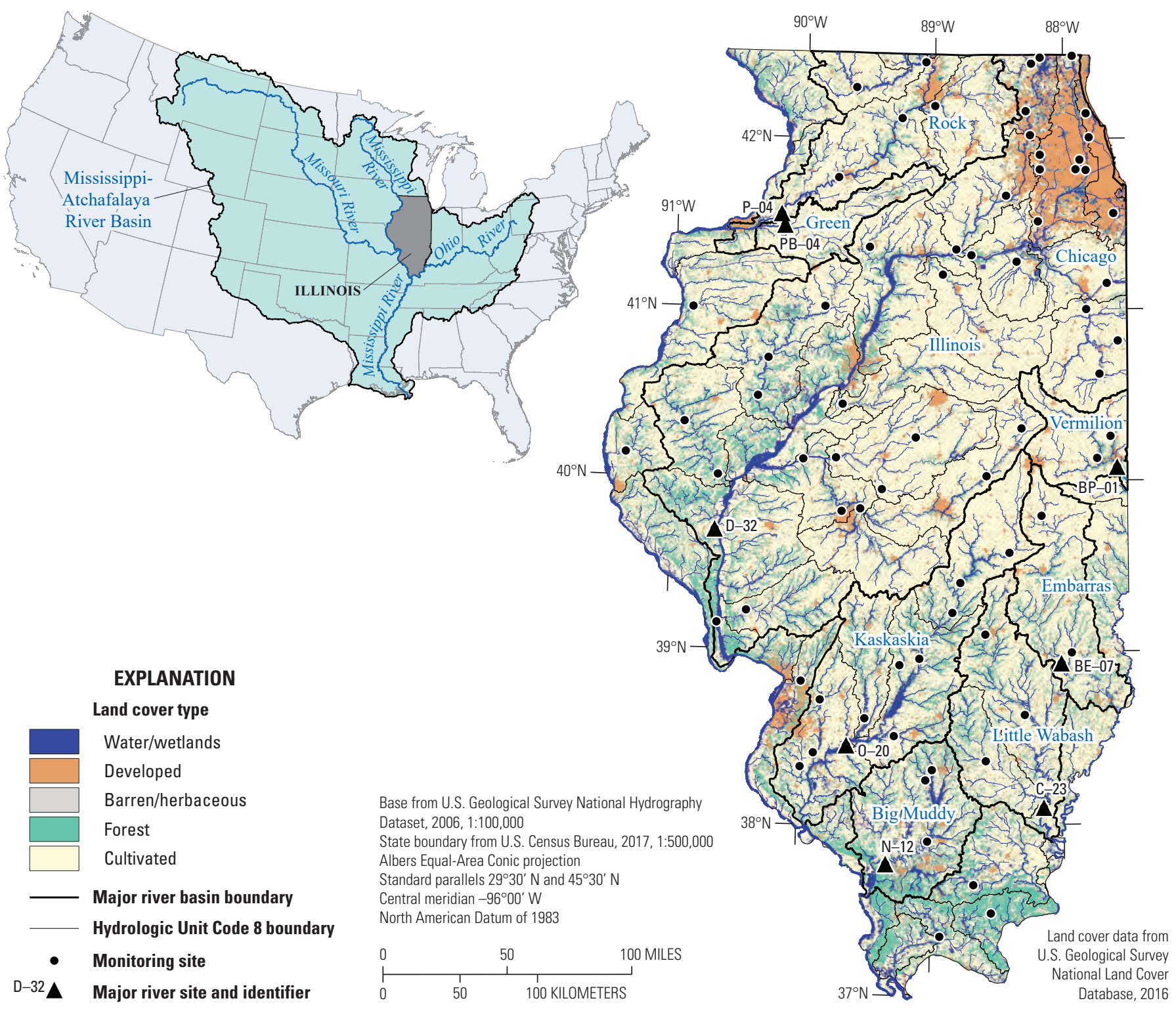

Figure 1. Locations of Ambient Water Quality Monitoring Network water-quality monitoring sites. Labels identify major river basins as well as the farthest downstream monitoring site in each major basin. Land use and land cover shown for Illinois is for 2011 (U.S. Geological Survey, 2014) with river flowlines (U.S. Geological Survey, 2018). 


\section{Methods}

Water-quality monitoring data used in this study were collected as part of the Illinois Environmental Protection Agency's Ambient Water Quality Monitoring Network (AWQMN). Data collection from the AWQMN began in 1957, but the network was redesigned in 1978 to provide more intensive monitoring and improve quality control (Wallin and Schaeffer, 1979). This report analyzes data collected after the 1978 redesign. As of 2019, the AWQMN monitors water quality at 146 stream and river sites across Illinois (appendix 1), many of which have been sampled at approximately 6-week intervals since the late 1970s or early 1980s. Of these sites, 78 are colocated with or represented by U.S. Geological Survey (USGS) streamgages that provide daily streamflow values. Only those AWQMN sites that also have streamflow data were analyzed in this study (fig. 1).

The AWQMN monitors a variety of constituents including nutrients, major ions, trace elements, and organic compounds. This study focused on constituents relevant to assessing changes in nutrient and soil loss: total phosphorus (TP), total nitrogen (TN), and TSS. Although TSS consist of more than just soil, when soil erodes, some of the eroded soil particles are carried by runoff or wind into nearby rivers and streams, which will increase TSS in that water body. For this reason, TSS are often used as a surrogate for soil loss. Trends in the main chemical fractions constituting TN and TP were also assessed, including the two fractions constituting TN: nitrate and nitrite (NO23) and total Kjeldahl nitrogen (TKN), which is organic nitrogen plus ammonia; and the two fractions constituting TP: particulate phosphorus (PP) and dissolved phosphorus (DP), measured as the orthophosphate in a filtered water sample. Typically, an AWQMN site only monitors the total nutrient concentration and the concentration of one of two nutrient fractions, or else only the two fractional components. In these cases, the missing component was estimated using the sum or difference of the other two components. For example, $\mathrm{TN}$ is the sum concentrations of TKN and NO23. Similarly, PP was estimated by subtracting DP from TP.

\section{Data Compilation}

All streamflow data were retrieved from the USGS National Water Information System database (USGS, 2016). Water-quality data collected by the AWQMN and used in this analysis were retrieved from the National Water Quality Monitoring Council Water Quality Portal (http://www.waterqualitydata.us). Some AWQMN sites were sampled as part of other monitoring efforts, potentially using different sampling methods or sampling in different locations in the streams. Because differences in methodology or location could produce artificial trends, data from non-AWQMN sampling efforts were not used in this analysis. Furthermore, changes in laboratory analytical methods or sample preservation methods through time could bias some of the trend results, as well as the interpretations. In most cases, correcting for these effects is either impracticable or impossible, and the potential bias induced by these factors was not assessed in this study. See Oelsner and others (2017) for further discussion of potential biases introduced by changes to analytical procedures.

\section{Trend Analysis}

Tests were performed to identify trends in flow-normalized (FN) concentration and flux of nutrients and TSS during two periods: 1978-2017 and 2008-17. The former period spans the CRP, CSP, and most of the CWA era and enables an assessment of the combined effects of changes in climate, population, land use, and watershed management on nutrient and soil loss since the inception of these programs. The latter period spans the years after these policies were already well established and, therefore, enables an assessment of their recent performance.

Year-to-year fluctuations in streamflow affect water quality of streams and rivers, which can confound the detection of water-quality trends (Hirsch and others, 2010). The effect of this random interannual variation in streamflow on water quality was removed using a process known as flow normalization, which uses probability distributions of daily streamflow to remove the effect of random streamflow variability on estimates of trends in concentration and flux (Hirsch and others, 2010, 2015).

Streamflow can also vary at longer time scales in response to long-term trends in climate or watershed management. To distinguish the effects of the longer-term trends in streamflow from those resulting from watershed management, the overall FN water-quality trends were subdivided into two components using an extension of the Weighted Regressions on Time, Discharge, and Season flow-normalization technique, known as generalized flow normalization (Choquette and others, 2019; Hirsch and Decicco, 2018; Murphy and Sprague, 2019).

The first trend component, known as the concentration-discharge trend component (CQTC), is the portion of change that arises from changes in how the constituent concentration and streamflow (discharge) covary through time. Another way to conceptualize the CQTC is the portion of change that arises from changes in the availability of nutrients from point and nonpoint sources within the watershed. Consequently, the CQTC is often considered as the portion of watershed change that is under human control. The other trend component, known as the streamflow trend component (QTC), is the portion of change arising from long-term changes in streamflow, which are at least partially controlled by climate and are outside the direct control of people within the watershed. This representation is only approximate, as climate change and human activities within the watershed can affect either trend component, but it is still useful for understanding the drivers of water-quality trends (Choquette and others, 2019; Murphy and Sprague, 2019). 
All water-quality trends and trend components in this report are FN and were computed with the EGRETci R-package using the Weighted Regression on Time, Discharge, and Season methodology (Hirsch and others, 2010; Hirsch and Decicco, 2018). Half-window widths of 7 years for time, 0.5 year for season, and 2 log cycles for discharge were used to calculate sample weights for a locally weighted regression, and a 15 -year sliding window was used to generate the flow probability distribution used in computing the FN concentration and flux trends. The probability that the trend direction was correct and the confidence interval (CI) about the trend magnitude were estimated using a block-bootstrap (BBS) approach (Hirsch and others, 2015, 2019). Trend CIs were estimated from 2,000 BBS replicates using the basic bootstrap method (Efron and Tibshirani, 1993, p. 171).

When reporting a trend, the "best" estimate, which is calculated using the entire sample, is followed by the 90-percent $\mathrm{CI}$ in parentheses, which is estimated using BBS. For example, an estimated 10 gigagram per year ( $\mathrm{Gg} / \mathrm{yr}$ ) change in flux with 90-percent confidence that the true value is between 5 and $25 \mathrm{Gg} / \mathrm{yr}$ would be reported as $10 \mathrm{Gg} / \mathrm{yr}(5-25 \mathrm{CI})$. The probability in the direction of the trend was reported following the terminology used by the Intergovernmental Panel on Climate Change (Mastrandrea and Mach, 2011). Trends with greater than 90-percent probability were specified as very likely, and trends with greater than 66-percent probability were specified as likely, where the probability was the percent of BBS replicates that trended in the same direction. If fewer than 66 percent of BBS replicates displayed the same trend direction, then the trend was taken to be insignificant.

In addition to site-by-site trends, statewide trends were estimated by summing the trends among Illinois' eight largest rivers based on the farthest downstream monitoring site on each river (table 1, fig. 1). Combined, the watersheds upstream from these monitoring sites cover 71 percent of the land area of Illinois, including the Chicago metropolitan area, as well as portions of Wisconsin and Indiana.

To provide additional insight into the underlying economic and population trends that might be affecting nutrient and soil losses, trends in corn and soybean production and cultivation area, the dominant crops grown in Illinois, and population change were estimated during the 1978-2017 and 2008-17 time periods using annual U.S. Department of Agriculture surveys (U.S. Department of Agriculture, 2019) and U.S. Census Bureau population estimates (U.S. Census Bureau, 2019). Population and agricultural production trends were estimated using the Sen slope estimator (Sen, 1968) and their magnitudes were calculated by multiplying the Sen slope estimate by the length of time over which the trend was estimated.
Table 1. Major river basins in Illinois, their farthest downstream Ambient Water Quality Monitoring Network identification, and the corresponding U.S. Geological Survey streamgage station number.

[AWQMN, Ambient Water Quality Monitoring Network; ID, identification; USGS, U.S. Geological Survey; km², square kilometer; \%, percent; --, not applicable]

\begin{tabular}{lcccc}
\hline \multicolumn{1}{c}{ River } & $\begin{array}{c}\text { AWOMN } \\
\text { ID }\end{array}$ & $\begin{array}{c}\text { USGS } \\
\text { streamgage } \\
\text { station }\end{array}$ & $\begin{array}{c}\text { Drainage } \\
\text { area } \\
\left.\mathbf{( k m}^{2}\right)\end{array}$ & $\begin{array}{c}\text { \% coverage } \\
\text { of Illinois }\end{array}$ \\
\hline Illinois & $\mathrm{D}-32$ & 05586100 & 69,264 & 39.9 \\
Rock & $\mathrm{P}-04$ & 05446500 & 24,732 & 7.3 \\
Kaskaskia & $\mathrm{O}-20$ & 05594100 & 11,378 & 7.8 \\
Little Wabash & $\mathrm{C}-23$ & 03381500 & 8,034 & 5.5 \\
Big Muddy & $\mathrm{N}-12$ & 05599500 & 5,618 & 3.8 \\
Embarras & $\mathrm{BE}-07$ & 03345500 & 3,926 & 2.7 \\
Vermillion & $\mathrm{BP}-01$ & 03339000 & 3,341 & 2.1 \\
Green & $\mathrm{PB}-04$ & 05447500 & 2,598 & 1.8 \\
Total & -- & - & $\mathbf{1 2 3 , 2 7 3}$ & $\mathbf{7 0 . 9}$ \\
\hline
\end{tabular}

\section{Trends in Nutrient and Soil Loss in Illinois Rivers, 1978-2017}

Changes in FN concentration, flux, and yield during the 1978-2017 and 2008-17 periods for TP, TN, and TSS are shown in figure 2. Statewide changes in annual flux during both periods are shown in figure 3 . Figures showing changes of the remaining constituents, as well as flux and yield changes for the major Illinois rivers, are included in appendix 2.

\section{Phosphorus, 1978-2017}

From 1978 through 2017, the FN concentration of TP very likely decreased at most sites, but FN flux likely increased by $2.2 \mathrm{Gg} / \mathrm{yr}(-0.8-5.7 \mathrm{CI})$ (fig. 3), with the largest increases occurring downstream from urban areas in the Illinois River Basin (fig. 2). The increase in TP flux was mainly attributable to the CQTC of DP, which very likely increased by $3.0 \mathrm{Gg} / \mathrm{yr}$ (1.2-4.2 CI), whereas PP showed no significant trend (fig. 3). In terms of yield, defined as flux per unit area per year, the Vermilion and Little Wabash River had the largest increases in TP (0.5 kilogram per hectare per year [( $\mathrm{kg} / \mathrm{ha}) / \mathrm{yr}]$ [-0.2-1.1 CI and 0.2-1 CI, respectively]), whereas the Green River had the largest significant decrease $(-0.3[\mathrm{~kg} / \mathrm{ha}] / \mathrm{yr}$ $[-0.7-0.5 \mathrm{CI}])($ table 2). 

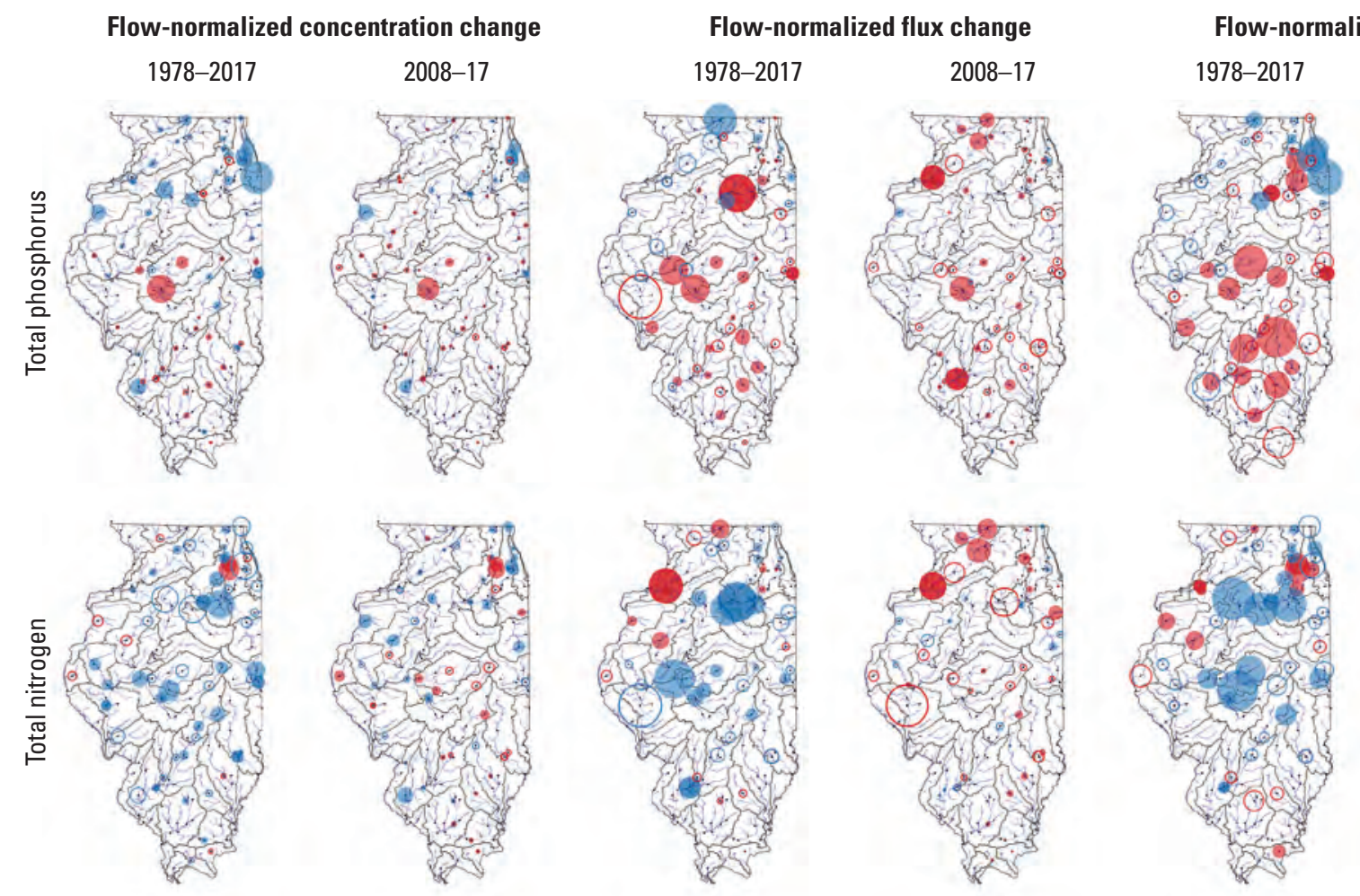

Flow-normalized yield change
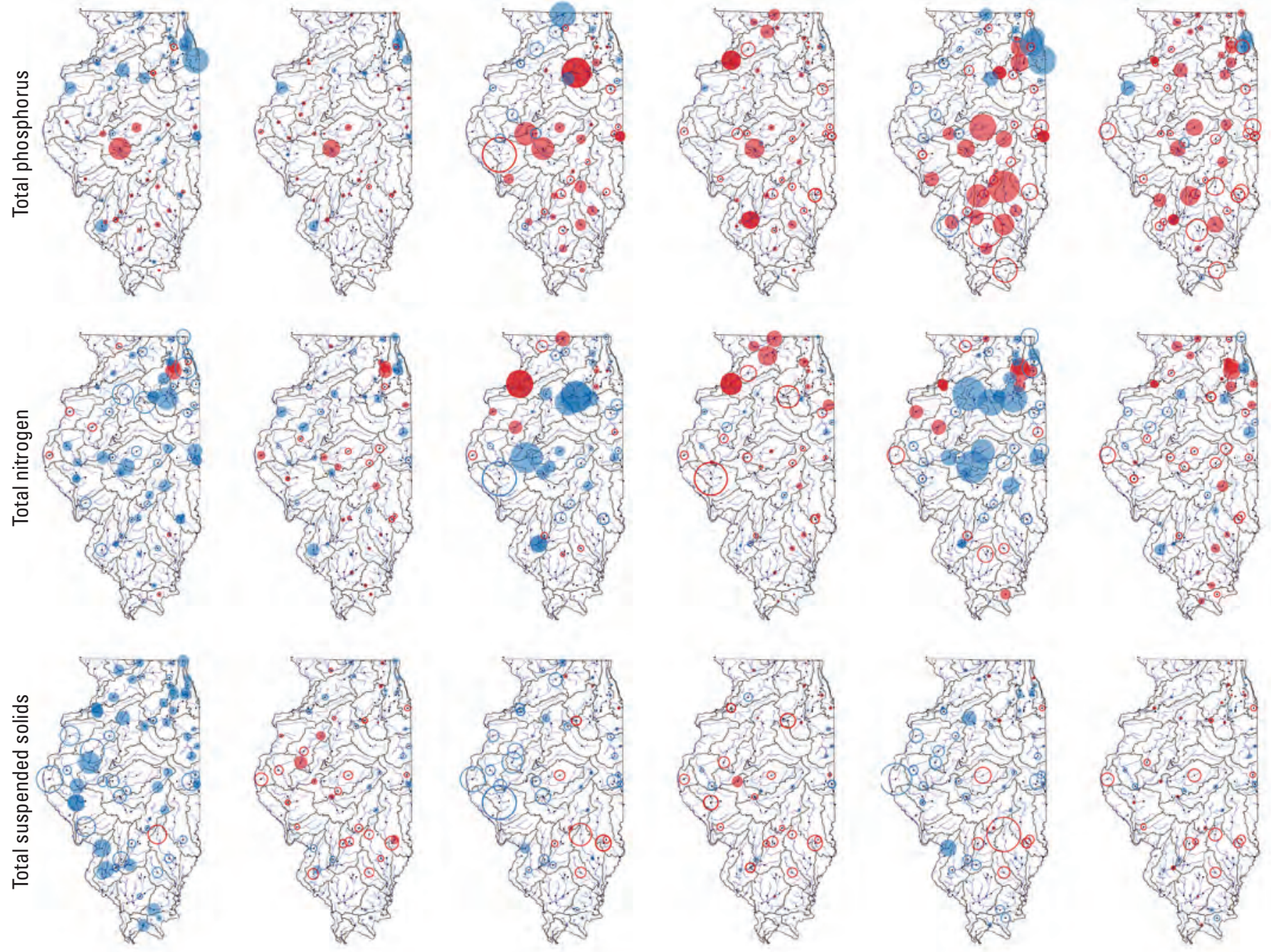

\section{EXPLANATION}

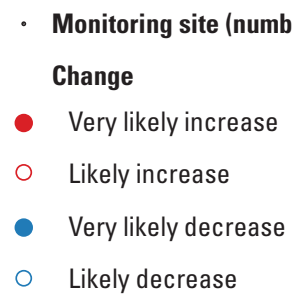

Figure 2. Maps of changes in flow-normalized concentration, flux, and yield of total phosphorus, total nitrogen, and total suspended solids. Change direction, magnitude, and likelihood denoted by the color, area, and style of the circle, respectively; circles are scaled independently for each constituent. Also shown are river flowlines and 8-digit hydrologic unit code (HUC 8) watershed boundaries (U.S. Geological Survey, 2018). 

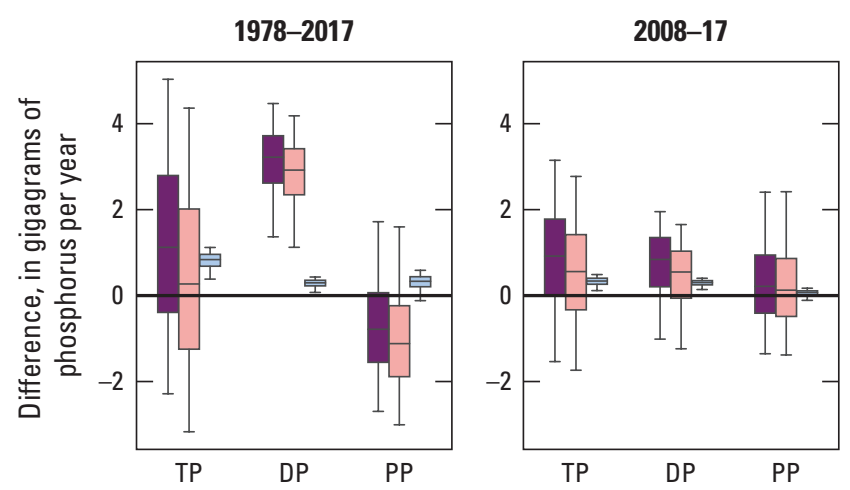

Table 2. Change in flow-normalized yield for each major river basin.

$[(\mathrm{kg} / \mathrm{ha}) / \mathrm{yr}$, kilogram per hectare per year; TP, total phosphorus; TN, total nitrogen; TSS, total suspended solids]
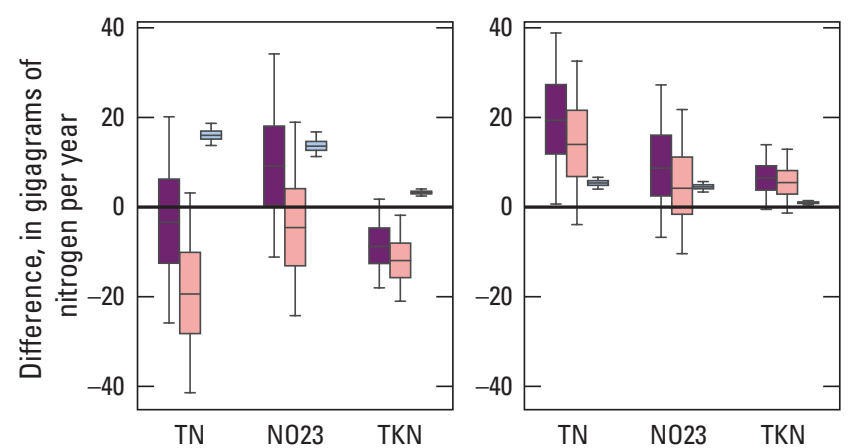

\begin{tabular}{rlrrr}
\hline \multirow{2}{*}{ Period } & \multicolumn{1}{c}{ River } & \multicolumn{3}{c}{ Yield change ([kg/ha]/yr) } \\
\cline { 3 - 5 } & & TP & TN & TSS \\
\hline \multirow{2}{*}{1978 to } & Illinois & 0.2 & -1.9 & -200 \\
& Rock & -0.1 & 3.6 & -40 \\
& Kaskaskia & 0.1 & -3.0 & 40 \\
& Little Wabash & 0.5 & 1.2 & -80 \\
& Big Muddy & 0.2 & -0.6 & 10 \\
& Embarras & 0.1 & -3.9 & 800 \\
& Vermilion & 0.5 & 0.75 & -100 \\
2008 to & Green & -0.3 & 2.0 & -300 \\
\hline \multirow{2}{*}{2017} & Illinois & 0.0 & 1.8 & 40 \\
& Rock & 0.2 & 2.3 & 40 \\
& Kaskaskia & 0.4 & -0.3 & 100 \\
& Bittle Wabash & 0.2 & 1.5 & 100 \\
& Embarras & 0.1 & 0.5 & 0 \\
& Vermilion & 0.7 & 2.2 & 800 \\
& Green & 0.3 & -0.8 & -200 \\
& & 0.1 & -0.4 & -10 \\
\hline
\end{tabular}

\section{Phosphorus, 2008-17}

From 2008 to 2017, TP trends followed a similar pattern to 1978-2017 (fig. 2), with concentrations decreasing at most sites, but FN flux increasing overall (fig. 3). Although the change in TP flux $(1.8 \mathrm{Gg} / \mathrm{yr}[-0.3-4.1 \mathrm{CI}])$ was smaller than during 1978-2017, the rate of change was likely higher because it occurred during a shorter period. Unlike the 1978-2017 period, during which most of the increase in TP flux occurred in the DP fraction, both DP and PP fractions likely contributed to increasing TP flux between 2008 and 2017 (fig. 3). In terms of TP yield, the Embarras River experienced the largest increase $(0.7[\mathrm{~kg} / \mathrm{ha}] / \mathrm{yr}[-0.6-1.2 \mathrm{CI}])$ (table 2). No major river experienced a significant decrease in TP yield during this period.

Figure 3. Statewide change in nutrient and total suspended solids fluxes for each trend component. Boxes and whiskers show the distribution of block-bootstrap replicates and correspond to the 50-percent and 90-percent confidence intervals, respectively. The line crossing through each box represents the median of the block-bootstrap replicates. 


\section{Nitrogen, 1978-2017}

From 1978 to 2017, the FN concentration and flux of TN decreased at most sites (fig. 2), and FN flux likely decreased statewide (fig. 3). The CQTC of TN very likely decreased by $-30 \mathrm{Gg} / \mathrm{yr}(-51--8 \mathrm{CI})$, but that decrease was partially negated by a very likely increase in the QTC of $22 \mathrm{Gg} / \mathrm{yr}$ (20-26 CI). Both TKN and NO23 contributed to the increase in the QTC, with the majority attributable to NO23 $(18 \mathrm{Gg} / \mathrm{yr}$ [16-22 CI]). In contrast, TKN and NO23 made similar contributions to decreasing the CQTC; the CQTC of TKN very likely decreased by $-14 \mathrm{Gg} / \mathrm{yr}(-22--2 \mathrm{CI})$, whereas $\mathrm{NO} 23$ likely decreased by $-15 \mathrm{Gg} / \mathrm{yr}(-34-7 \mathrm{CI})$. In terms of TN yield, the Rock River had the largest increase $(3.6[\mathrm{~kg} / \mathrm{ha}] / \mathrm{yr}$ [1.8-5.3 CI]), whereas the Embarras River had the largest decrease $(-3.9[\mathrm{~kg} / \mathrm{ha}] / \mathrm{yr}[-6.3-0.6 \mathrm{CI}])$ (table 2).

\section{Nitrogen, 2008-17}

From 2008 to 2017, the FN concentration and flux of $\mathrm{TN}$ increased at most sites (fig. 2), whereas statewide FN flux of TN likely increased by $20 \mathrm{Gg} / \mathrm{yr}(0-40 \mathrm{CI})$ (fig. 3). Both the streamflow and management trend components contribute to the increase, with the CQTC likely increasing $8 \mathrm{Gg} / \mathrm{yr}(-11-22 \mathrm{CI})$ and QTC very likely increasing $12 \mathrm{Gg} / \mathrm{yr}$ $(10-14 \mathrm{CI})$. The change in flux of TN was split between NO23 and TKN, with NO23 likely increasing by $8 \mathrm{Gg} / \mathrm{yr}(-11-20 \mathrm{CI})$ and TKN very likely increasing by $8 \mathrm{Gg} / \mathrm{yr}(1-15 \mathrm{CI})$. Most of the statewide increase in flux of TN during this decade occurred in the Rock and Illinois Rivers (appendix fig. 2.4). In terms of TN yield, the Rock River and the Embarras River had the largest increase, which were $2.3(\mathrm{~kg} / \mathrm{ha}) / \mathrm{yr}(0.5-3.7 \mathrm{CI})$ and $2.2(\mathrm{~kg} / \mathrm{ha}) / \mathrm{yr}(-3.6-6.5 \mathrm{CI})$, and the Vermilion River had the largest decrease, which was $-0.8(\mathrm{~kg} / \mathrm{ha}) / \mathrm{yr}(-6.0-3.1 \mathrm{CI})$ (table 2).

\section{Total Suspended Solids, 1978-2017}

From 1978 to 2017, the FN concentration and flux of TSS decreased at most sites (fig. 2). The largest decreases in flux occurred in the Illinois River Basin; however, fluxes increased in several watersheds in southern Illinois. Statewide, the flux of TSS likely decreased by $-1,500 \mathrm{Gg} / \mathrm{yr}(-4,100-2,000 \mathrm{CI})$ during this period. This decrease was entirely attributable to the CQTC, which likely decreased $-2,000 \mathrm{Gg} / \mathrm{yr}$ $(-4,600-1,400 \mathrm{CI})$, whereas QTC very likely increased $500 \mathrm{Gg} / \mathrm{yr}(300-900 \mathrm{CI})$ (fig. 3). In terms of TSS yield, the Embarras River had the largest increase $(800[\mathrm{~kg} / \mathrm{ha}] / \mathrm{yr}$
$[-1,300-1,600 \mathrm{CI}])$, and the Green River had the largest decrease $(-300[\mathrm{~kg} / \mathrm{ha}] / \mathrm{yr}[-5,000-400 \mathrm{CI}])$ (table 2).

\section{Total Suspended Solids, 2008-17}

From 2008 to 2017, the FN concentration and flux of TSS increased at most sites, whereas the statewide flux of TSS likely increased by $700 \mathrm{Gg} / \mathrm{yr}(-400-2,300 \mathrm{CI})$. Most of that increase was attributed to the CQTC, which likely increased by $400 \mathrm{Gg} / \mathrm{yr}(-600-2,000 \mathrm{CI})$, as well as a smaller but very likely QTC increase of $300 \mathrm{Gg} / \mathrm{yr}(200-400 \mathrm{CI})$. In terms of TSS yield, the Embarras River had the largest increase (800 [kg/ha] $/ \mathrm{yr}[-1,000-1,400 \mathrm{CI}])$, and the Vermilion River had the largest decrease $(-200[\mathrm{~kg} / \mathrm{ha}] / \mathrm{yr}[-600-200 \mathrm{CI}])$ (table 2).

\section{Synopsis and Implications of Trends in Nutrient and Soil Loss}

Three main trends emerged from this analysis: (1) during the past four decades (1978-2017), changes in watershed management (as indicated by the CQTC) very likely resulted in a decrease in soil loss (approximated as TSS) and TN loss, but likely resulted in an increase in TP loss; (2) any effects from watershed management efforts were partially or entirely negated by long-term streamflow trends (as indicated by the QTC); and (3) during the past decade (2008-17), rates of nutrient and soil loss very likely increased.

\section{Trends during 1978-2017}

From 1978 to 2017, the flux of TN from Illinois rivers likely decreased overall, with larger but opposing trends resulting from streamflow (QTC) and watershed management (CQTC). This pattern of opposing CQTC and QTC, with little overall change, can indicate limitation in nutrient availability, rather than changes in watershed management (Choquette and others, 2019). When nutrient availability within a watershed is fixed and streamflow increases, the nutrient is diluted, thereby causing CQTC to decrease. Although such a dilution effect might explain much of the TN trend during this period, some trends within individual watersheds or nitrogen fractions cannot be explained solely by supply limitation. For example, there is a likely reduction in TKN loss due to improvements in management in rural watersheds (manifested in the CQTC) (fig. 2.6), and a very likely increase in NO23 flux from the Rock River due to changing streamflow (fig. 2.4). 
Although nutrients are not truly conservative in an aquatic system, they can, under certain circumstances, be approximated as such. In other words, the downstream flux of a nutrient is assumed to be equal to its upstream input. This assumption is tenuous at local scales, especially around lakes and reservoirs, but it appears to hold at regional scales, at least in the case of NO23 (McIsaac and others, 2001). This semiconservative behavior might emerge, in part, because most nutrient flux occurs during short-duration storm events, when in-stream residence is short, allowing less time for in-stream nutrient cycling. Phosphorus is more prone to cycling, so the assumption that it behaves conservatively warrants additional skepticism. Though imperfect, the assumption that nutrients behave conservatively can help disentangle the effects of different management practices within a watershed if the specific nutrient forms can be uniquely associated with specific sources. As an example, rural watersheds in Illinois experienced widespread decreases in fluxes of TKN after 1978 (appendix figs. 2.2, 2.4, and 2.6). Experiments indicate soil erosion and TKN loss are highly correlated in fields under row-crop corn and soybean cultivation (McIsaac and others, 1991). From 1978 to 2017, TSS, a proxy for soil erosion, likely decreased statewide by 22 percent $(-31-63 \mathrm{CI})$, mostly due to reductions in the CQTC, which likely decreased 32 percent $(-21-72 \mathrm{CI})$. Because corn and soybean cultivation are the predominant land uses in Illinois, the concurrent decreases in TSS and TKN (fig. 3) might indicate that improvements in soil conservation played an important role in mitigating nitrogen losses. In contrast, rural NO23 trends were more variable, which might reflect the inefficacy of soil conservation to control NO23 loss, which typically occurs by way of leaching, rather than from soil erosion.

Although fluxes of TN and TSS decreased during 1978-2017, the statewide flux of TP likely increased by 15 percent (-6-41 CI), driven by a likely increase in the CQTC and a very likely increase in the QTC. This increase was largely driven by increasing fluxes of DP from the Illinois River that can be traced back to major urban areas upstream (fig. 2, appendix fig. 2.1), like the Chicago metropolitan area, which grew by 1.5 million residents during the same period (fig. 4; U.S. Census Bureau, 2019). Population growth would result in more wastewater, which might explain the increase in DP. Roughly one-half of the phosphorus transported through Illinois rivers is derived from nonpoint sources, the largest of which is thought to be soil erosion in agricultural watersheds (Illinois Environmental Protection Agency, 2015). Like nitrogen, the effect of soil conservation should be most apparent in the particulate fraction, because most phosphorus in soil occurs in the particulate form (Reid and others, 2018). Although improvements in soil conservation should also mitigate PP loss, there was no significant decrease in PP flux between 1978 and 2017, despite decreases in other proxies for soil loss like TSS. The lack of a decrease could indicate that the benefits of soil conservation were outpaced by other factors affecting PP loss. Alternatively, PP may be a poor surrogate for rural soil erosion, either because phosphorus is more prone to cycle between dissolved and particulate phases or there were large contributions of PP from urban sources.
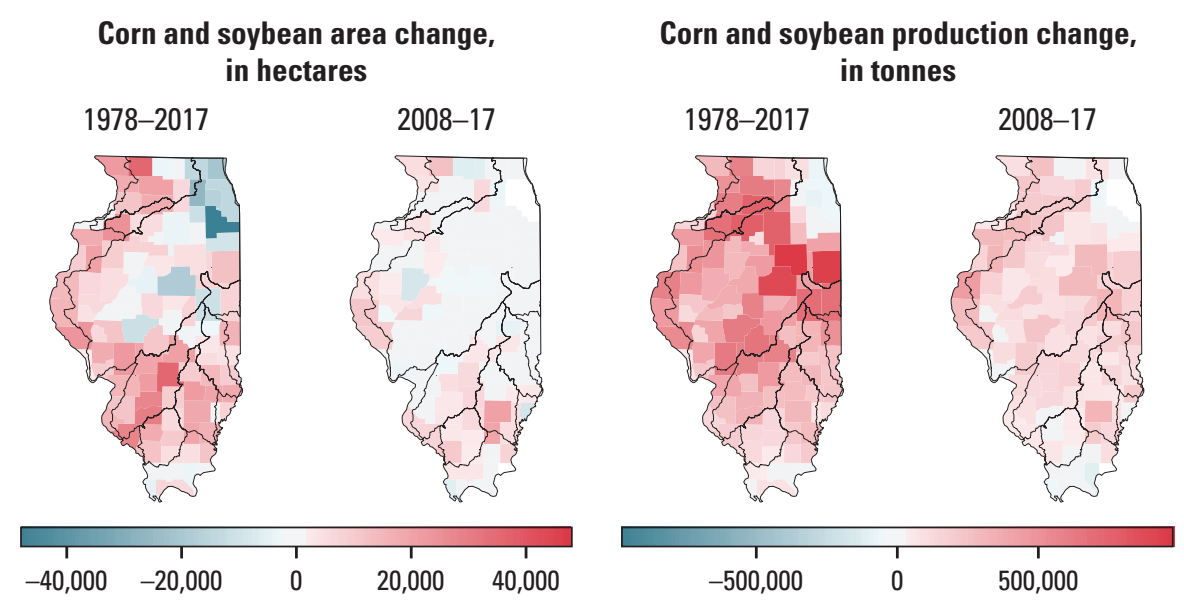

Population change

Figure 4. Change in corn and soybean area and production (U.S. Department of Agriculture, 2019), as well as population change (U.S. Census Bureau, 2019), among counties in Illinois, 1978-2017. 
Overall, fluxes of TSS and TN likely decreased, whereas TP likely increased in Illinois rivers between 1978 and 2017. During the same period, corn and soybean production increased 86 percent and population increased 18 percent (fig. 4; U.S. Census Bureau, 2019). These relations indicate the reductions in TKN and TSS resulted, at least in part, from better watershed management, rather than declining agricultural production or population. This finding has important implications for efforts to curb nutrient and soil loss. Illinois' increase in agricultural production between 1978 and 2017 was similar in magnitude and rate to what will be required in many developing countries to feed a global population of 9.8 billion by 2050 (Alexandratos and Bruinsma, 2012). Although Illinois may not be an ideal analog for every region, its experience might be informative. Simply knowing that agricultural growth of this magnitude can occur without severe degradation of water quality can be viewed as encouraging to policymakers considering whether to invest in large-scale land-management programs, especially because some of the same conservation practices applied in Illinois, such as conservation tillage and use of cover crops, are suited to a wide range of environmental settings.

Although improved management of agricultural nonpoint sources might have stemmed nitrogen and soil losses, those efforts appear to have had less effect on mitigating phosphorus loss. Unlike nitrogen and sediment, point sources are the largest source of phosphorus in Illinois waters (Illinois Environmental Protection Agency, 2015). Consequently, programs like CSP or CRP, which primarily target nonpoint agricultural sources, are less likely to mitigate the main sources of phosphorus, which instead fall under the purview of the CWA. Most investment into the CWA, however, has gone toward funding the construction of wastewater treatment plants, which traditionally do not remove phosphorus from wastewater. This might explain why, despite improving overall water quality, the CWA has not had a demonstrated effect on mitigating phosphorus loss.

\section{Trends during 2008-17}

From 2008 to 2017, fluxes of TN, TP, and TSS from Illinois watersheds all likely increased. Compared to the 1978-2017 period, fluxes of TN and TSS switched from decreasing to increasing, whereas the rate of increase in flux of TP likely increased. Nutrient and TSS fluxes increased in most major river basins, as well as downstream from the Chicago metropolitan area (appendix figs. 2.1-2.4). The relative contributions of agricultural runoff as compared to other point sources are uncertain, but the increasing fluxes of TSS, PP, and TKN during 2008-17 indicate increasing soil erosion was a factor. Streamflow trends (as indicated by the QTC) also made significant contributions to these increases, particularly in the Rock and Illinois Rivers (appendix figs. 2.3-2.6). Among all the constituents assessed in this study, only NO23 did not significantly increase during 2008-17. For every other constituent, watershed management likely failed to keep pace with socioeconomic and climate trends responsible for increasing nutrient and soil loss (fig. 2).

Increases in Illinois' agricultural production and population were smaller during 2008-17 than during 1978-2017 (fig. 4). Population remained stable and corn and soybean production grew by 18 percent from 2008 to 2017, whereas population and corn and soybean production both grew from 1978 to 2017 (18 percent and 86 percent, respectively). Therefore, increasing nutrient and soil loss during 1978-2017 occurred despite decreasing rates of agricultural and population growth. One explanation for these trends could be that the expansionary periods of the CWA, CSP, and CRP were largely complete by 2008 and, as a result, most of the initial gains from these policies were realized prior to 2008. Consequently, socioeconomic and climate changes since 2008 have had a disproportionate effect because they were not offset by proportional investment toward reducing soil and nutrient loss. Alternatively, accelerating nutrient and soil loss might reflect a loss of efficacy of existing management. At some point, diminishing returns could create a threshold across which the economics of conservation become less favorable. For example, once soil conservation is implemented on the most vulnerable land areas within a watershed, further investments in conservation become less effective at mitigating erosion, or as agricultural production expands onto more vulnerable land, greater investments in conservation are required to mitigate soil and nutrient loss.

One global concern is that as farmers apply more fertilizer to boost yields, fertilizer-use efficiency will decrease, resulting in greater nutrient loss (Lassaletta and others, 2014). In Illinois, at least, the recent increase in crop yield does not appear to be at the expense of fertilizer-use efficiency. To the contrary, fertilizer use and NO23 loss were stable during the past decade (Brakebill and Gronberg, 2017; U.S. Department of Agriculture, 2018) while corn and soybean yields increased, implying fertilizer use-efficiency has improved. 


\section{Summary}

Nutrient and soil loss, defined herein as the loss of nutrients or soil to streams and other downstream receiving waters, affect watersheds around the globe. Although governments make large investments mitigating nutrient and soil loss through watershed management efforts, the efficacy of these efforts is often difficult to assess, in part because streamflow variability obscures the effects.

This study investigates the effects of watershed management on nutrient and soil losses in the State of Illinois during two periods: 1978 to 2017, and 2008 to 2017. The former period provides an important test case for assessing the efficacy of major Federal programs like the Clean Water Act and the Conservation Reserve Program at mitigating nutrient and soil loss, whereas the latter spans the years after these policies were well established, thereby providing an assessment of whether these programs have kept pace with ongoing trends in climate and watershed management.

The effect of interannual streamflow variability on long-term nutrient and soil loss trends was removed using an extension of the Weighted Regressions on Time, Discharge, and Season methodology, called generalized flow normalization. This process also partitions trends into components attributable to long-term changes in streamflow and watershed management. The Weighted Regressions on Time, Discharge, and Season trend analysis indicated significant, widespread trends in nutrient and soil loss in Illinois since 1978.

During the past four decades, changes in watershed management have decreased soil and nitrogen loss in Illinois, even as agricultural production and population grew. However, these gains were completely or partially negated by long-term streamflow trends, which might, in part, be caused by climate change. Meanwhile, phosphorus loss in Illinois increased, possibly due to a combination of changing streamflow and inadequate management of point sources.

During 2008-17, however, soil and nutrient loss increased, despite smaller increases in agricultural production and a stable population. This shift appears to be largely the result of increasing streamflow and soil erosion. Inadequate management of dissolved phosphorus, which is typically associated with point sources, was also a contributor. These findings might indicate that agricultural production within the State of Illinois has passed a threshold across which smaller gains in crop production are causing larger increases in nutrient and soil loss. Alternatively, the efficacy of management efforts may be unchanged, but rather investment toward protecting water resources has not kept pace with the socioeconomic and climate trends responsible for nutrient and soil loss. Additional research is needed to investigate which of these scenarios is more likely. In either case, investment toward reducing soil and nutrient loss will need to increase if improvements in these areas are to be sustained.

\section{References}

Alexandratos, N., and Bruinsma, J., 2012, World agriculture towards 2030/2050 - The 2012 revision: ESA Working Paper No. 12-03, no. 12, 154 p. [Also available at http://www.fao.org/3/a-ap106e.pdf.]

Borrelli, P., Robinson, D.A., Fleischer, L.R., Lugato, E., Ballabio, C., Alewell, C., Meusburger, K., Modugno, S., Schütt, B., Ferro, V., Bagarello, V., Van Oost, K., Montanarella, L., and Panagos, P., 2017, An assessment of the global impact of 21 st century land use change on soil erosion: Nature Communications, v. 8. [Also available at https://doi.org/10.1038/s41467-017-02142-7.]

Brakebill, J.W., and Gronberg, J.M., 2017, County-level estimates of nitrogen and phosphorus from commercial fertilizer for the conterminous United States, 1987-2012: U.S. Geological Survey data release, accessed June 2019 at https://doi.org/10.5066/F7H41PKX.

Brink, R.A., Densmore, J.W., and Hill, G.A., 1977, Soil deterioration and the growing world demand for food: Science, v. 197, no. 4304, p. 625-630. [Also available at https://doi.org/10.1126/science.197.4304.625.]

Committee on Environmental and Natural Resources, 2000, Integrated assessment of hypoxia in the Northern Gulf of Mexico: Washington, D.C., National Science and Technology Council Committee on Environment and Natural Resources, 58 p. [Also available at https://www.epa.gov/ms-htf/integrated-assessment-hypoxianorthern-gulf-mexico-and-hypoxia-assessment-reports.]

Choquette, A.F., Hirsch, R.M., Murphy, J.C., Johnson, L.T., and Confesor, R.B., Jr., 2019, Tracking changes in nutrient delivery to western Lake Erie-Approaches to compensate for variability and trends in streamflow: Journal of Great Lakes Research, v. 45, no. 1, p. 21-39. [Also available at https://doi.org/10.1016/j.jglr.2018.11.012.]

Dodds, W.K., Bouska, W.W., Eitzmann, J.L., Pilger, T.J., Pitts, K.L., Riley, A.J., Schloesser, J.T., and Thornbrugh, D.J., 2009, Eutrophication of U.S. freshwaters - Analysis of potential economic damages: Environmental Science \& Technology, v. 43, no. 1, p. 12-19. [Also available at https://doi.org/10.1021/es801217q.]

Dubrovsky, N.M., Burow, K.R., Clark, G.M., Gronberg, J.M., Hamilton, P.A., Hitt, K.J., Mueller, D.K., Munn, M.D., Nolan, B.T., Puckett, L.J., Rupert, M.G., Short, T.M., Spahr, N.E., Sprague, L.A., and Wilber, W.G., 2010, The quality of our Nation's waters-Nutrients in the Nation's streams and groundwater, 1992-2004:

U.S. Geological Survey Circular 1350, 174 p. Additional information about this study is available at https:/water.usgs.gov/nawqa/nutrients/pubs/circ1350. 
Efron, B., and Tibshirani, R., 1993, An introduction to the bootstrap: Boca Raton, Fla., Chapman \& Hall/CRC, 456 p. [Also available at https:/www.taylorfrancis.com/books/9780429246593.]

Eswaran, H., Lal, R., and Reich, P.F., 2001, Land degradation-An overview, in Bridges, E.M., Hannam, I.D., Oldeman, L.R., Pening de Vries, F.W.T., Scherr, S.J., and Sompatpanit, S., eds., Responses to land degradation: Proceedings of the 2nd International Conference on Land Degradation and Desertification, Khon Kaen, Thailand, Oxford Press, New Delhi, India. [Also available at https://www.nrcs.usda.gov/wps/portal/nres/detail/soils/use/? cid=nrcs142p2_054028.]

Fuglie, K.O., 2010, Total factor productivity in the global agricultural economy-Evidence from FAO data, chap. 4 of Alston, J.M., Babcock, B.A., and Pardey, P.G., eds., The shifting patterns of agricultural production and productivity worldwide: Ames, Iowa: Iowa State University Midwest Agribusiness Trade Research and Information Center, p. 63-95. [Also available at https://www.card.iastate.edu/ products/books/shifting_patterns/pdfs/chapter4.pdf.]

Galloway, J.N., Aber, J.D., Erisman, J.W., Seitzinger, S.P., Howarth, R.W., Cowling, E.B., and Cosby, J.B., 2003, The nitrogen cascade: Bioscience, v. 53, no. 4, p. 341-356. [Also available at https://doi.org/10.1641/00063568(2003)053[0341:TNC]2.0.CO;2.]

Hauer, C., Leitner, P., Unfer, G., Pulg, U., Habersack, H., and Graf, W., 2018, The role of sediment and sediment dynamics in the aquatic environment, in Schmutz, S., and Sendzimir, J., eds., Riverine ecosystem management: Springer v. 8. Aquatic Ecology Series, p. 151-169. [Also available at https://doi.org/10.1007/978-3-319-73250-3_8.]

Heisler, J., Glibert, P.M., Burkholder, J.M., Anderson, D.M., Cochlan, W., Dennison, W.C., Dortch, Q., Gobler, C.J., Heil, C.A., Humphries, E., Lewitus, A., Magnien, R., Marshall, H.G., Sellner, K., Stockwell, D.A., Stoecker, D.K., and Suddleson, M., 2008, Eutrophication and harmful algal blooms-A scientific consensus: Harmful Algae, v. 8, no. 1, p. 3-13. [Also available at https://doi.org/10.1016/j.hal.2008.08.006.]

Hirsch, R.M., Archfield, S.A., and De Cicco, L.A., 2015, A bootstrap method for estimating uncertainty of water quality trends: Environmental Modelling \& Software, v. 73, p. 148-166. [Also available at https://doi.org/10.1016/j.envsoft.2015.07.017.].

Hirsch, R.M., and Decicco, L., 2018, Guide to EGRET 3.0 enhancements: accessed March 14, 2019, at https://cran.r-project.org/web/packages/EGRET/vignettes/ Enhancements.html.
Hirsch, R.M., DeCicco, L., and Murphy, J.C., 2019, Exploration and graphics for RivEr trends confidence intervals (Version 2.0.2): R package, accessed August 2019 at https://rdrr.io/cran/EGRETci/.

Hirsch, R.M., Moyer, D.L., and Archfield, S.A., 2010, Weighted regressions on time, discharge, and season (WRTDS), with an application to Chesapeake Bay River inputs: Journal of the American Water Resources Association, v. 46, no. 5, p. 857-880. [Also available at https://doi.org/10.1111/j.1752-1688.2010.00482.x.]

Illinois Environmental Protection Agency, 2015, Illinois Nutrient Loss Reduction Strategy: Illinois Environmental Protection Agency, 171 p. [Also available at https://www2.illinois.gov/epa/Documents/iepa/waterquality/watershed-management/nlrs/nlrs-final-revised083115.pdf.]

Lassaletta, L., Billen, G., Grizzetti, B., Anglade, J., and Garnier, J., 2014, 50 year trends in nitrogen use efficiency of world cropping systems - The relationship between yield and nitrogen input to cropland: Environmental Research Letters, v. 9, no. 10, 9 p. [Also available at https://doi.org/10.1088/1748-9326/9/10/105011.]

Markus, M., Demissie, M., Short, M.B., Verma, S., and Cooke, R.A., 2014, Sensitivity analysis of annual nitrate loads and the corresponding trends in the Lower Illinois River: Journal of Hydrologic Engineering, v. 19, no. 3, p. 533-543. [Also available at https://doi.org/10.1061/ (ASCE)HE.1943-5584.0000831.]

Mastrandrea, M.D., and Mach, K.J., 2011, Treatment of uncertainties in IPCC assessment reports-Past approaches and considerations for the Fifth Assessment Report: Climatic Change, v. 108, no. 4, p. 659-673. [Also available at https://doi.org/10.1007/s10584-011-0177-7.]

McIsaac, G.F., David, M.B., and Gertner, G.Z., 2016, Illinois River nitrate-nitrogen concentrations and loads - Long-term variation and association with watershed nitrogen inputs: Journal of Environmental Quality, v. 45, no. 4, p. 1268-1275. [Also available at https://doi.org/10.2134/jeq2015.10.0531.]

McIsaac, G.F., David, M.B., Gertner, G.Z., and Goolsby, D.A., 2001, Nitrate flux in the Mississippi River: Nature, v. 414, p. 166-167. [Also available at https://doi.org/10.1038/35102672.]

McIsaac, G.F., Hirschi, M.C., and Mitchell, J.K., 1991, Nitrogen and phosphorus in eroded sediment from corn and soybean tillage systems: Journal of Environmental Quality, v. 20, no. 3, p. 663-670. [Also available at https://doi.org/ 10.2134/jeq1991.00472425002000030026x.] 
Meals, D.W., Dressing, S.A., and Davenport, T.E., 2010, Lag time in water quality response to best management practices-A review: Journal of Environmental Quality, v. 39, no. 1, p. 85-96. [Also available at https://doi.org/10.2134/jeq2009.0108.]

Mississippi River/Gulf of Mexico Watershed Nutrient Task Force, 2015, Mississippi River/Gulf of Mexico Watershed Nutrient Task Force 2015 Report to Congress: Washington, D.C., U.S. Environmental Protection Agency, Office of Wetlands, Oceans and Watersheds, Mississippi River/Gulf of Mexico Nutrient Task Force, p. 98. [Also available at https://www.epa.gov/ms-htf/hypoxia-task-force-reportscongress.]

Montgomery, D.R., 2007, Soil erosion and agricultural sustainability: Proceedings of the National Academy of Sciences of the United States of America, v. 104 , no. 33 , p. 13268-13272. [Also available at https://doi.org/10.1073/pnas.0611508104.]

Murphy, J.C., Hirsch, R.M., and Sprague, L.A., 2013, Nitrate in the Mississippi River and its tributaries, 1980-2010-An update: U.S. Geological Survey Scientific Investigations Report 2013-5169, p. 31. [Also available at https://doi.org/10.3133/sir20135169.]

Murphy, J., and Sprague, L., 2019, Water-quality trends in US rivers-Exploring effects from streamflow trends and changes in watershed management: The Science of the Total Environment, v. 656, p. 645-658. [Also available at https://doi.org/10.1016/j.scitotenv.2018.11.255.]

Myers, D.N., and Ludtke, A.S., 2017, Chapter two-Progress and lessons learned from water-quality monitoring networks, in Ahuja, S., and others, eds., Chemistry and water-The science behind sustaining the world's most crucial resource: Elsevier Inc., p. 23-120. [Also available at https://doi.org/10.1016/B978-0-12-809330-6.00002-7.]

Noone, K., Sumaila, R., and Diaz, R.J., eds., 2012, Valuing the ocean-Extended executive summary. Stockholm Environmental Institute, 27 p. [Also available at https:/mediamanager.sei.org/documents/Publications/ SEI-Report-ValuingTheOcean-ExtendedSummaryReport2012.pdf.]

Oelsner, G.P., Sprague, L.A., Murphy, J.C., Zuellig, R.E., Johnson, H.M., Ryberg, K.R., Falcone, J.A., Stets, E.G., Vecchia, A.V., Riskin, M.L., De Cicco, L.A., Mills, T.J., and Farmer, W.H., 2017, Water-quality trends in the Nation's rivers and streams, 1972-2012-Data preparation, statistical methods, and trend results (ver. 2.0, October 2017): U.S. Geological Survey Scientific Investigations Report 2017-5006, 136 p. [Also available at https://doi.org/10.3133/sir20175006.]
Reay, D.S., Davidson, E.A., Smith, K.A., Smith, P., Melillo, J.M., Dentener, F., and Crutzen, P.J., 2012, Global agriculture and nitrous oxide emissions: Nature Climate Change, v. 2, no. 6, p. 410-416. [Also available at https://doi.org/10.1038/nclimate1458.]

Reid, K., Schneider, K., and McConkey, B., 2018, Components of phosphorus loss from agricultural landscapes, and how to incorporate them into risk assessment tools: Frontiers in Earth Science, v. 6, p. 1-15. [Also available at https://www.frontiersin.org/articles/ 10.3389/feart.2018.00135/full.]

Robertson, D.M., Saad, D.A., and Schwarz, G.E., 2014, Spatial variability in nutrient transport by HUC8, state, and subbasin based on Mississippi/Atchafalaya River Basin SPARROW models: Journal of the American Water Resources Association, v. 50, no. 4, p. 988-1009. [Also available at https://doi.org/10.1111/jawr.12153.]

Sen, P.K., 1968, Estimates of the regression coefficient based on Kendall's tau: Journal of the American Statistical Association, v. 63, no. 324, p. 1379-1389. [Also available at https://doi.org/10.1080/01621459.1968.10480934.]

United Nations, Department of Economic and Social Affairs, Population Division, 2017, World population prospectsThe 2017 revision, key findings and advance tables: Working Paper No. ESA/P/WP/248, p. 47. [Also available at https://reliefweb.int/report/world/world-populationprospects-2017-revision-key-findings-and-advance-tables.]

U.S. Census Bureau, 2019, U.S. Census Bureau population estimates program: accessed April 16, 2019, at https://www.census.gov/programs-surveys/popest.html.

U.S. Department of Agriculture, 2018, Fertilizer use and price: U.S. Department of Agriculture, Economic Research Service, accessed April 2019, at https://www.ers.usda.gov/ data-products/fertilizer-use-and-price.aspx.

U.S. Department of Agriculture, 2019, National Agricultural Statistics Service: accessed April 2019 at https://quickstats.nass.usda.gov.

U.S. Environmental Protection Agency [EPA], 2010, Clean watersheds needs survey 2008-Report to Congress: U.S. Environmental Protection Agency Office of Wastewater Management Report EPA-832-R-10-002, $154 \mathrm{p}$. [Also available at https://www.epa.gov/cwns/cleanwatersheds-needs-survey-cwns-report-congress-2008.]

U.S. Environmental Protection Agency [EPA], 2018, Biofuels and the environment-The second triennial report to Congress: Washington, D.C., U.S. Environmental Protection Agency, EPA/600/R-18/195, 159 p. [Also available at https://cfpub.epa.gov/si/si_public_record_report.cfm?Lab= IO\&dirEntryId=341491.] 
U.S. Geological Survey [USGS], 2014, National land cover database 2011, amended 2014 (NLCD 2011): U.S. Geological Survey database, accessed April 2019 at https://www.mrlc.gov/data/nlcd-2011-land-cover-conus-0.

U.S. Geological Survey [USGS], 2016, USGS water data for the Nation: U.S. Geological Survey National Water Information System database, accessed April 2019 at https://doi.org/10.5066/F7P55KJN.

U.S. Geological Survey, 2018, National Hydrography Dataset: U.S. Department of the Interior, U.S. Geological Survey dataset, accessed April 2019 at https://www.usgs.gov/ core-science-systems/ngp/national-hydrography/nationalhydrography-dataset.
Wallander, S., Claassen, R., and Nickerson, C., 2011, The ethanol decade-An expansion of U.S. corn production, 2000-09: Economic Research Service Economic Information Bulletin, no. 79, 22 p. [Also available at https://www.ers.usda.gov/publications/pub-details/? pubid $=44566$.]

Wallin, T.R., and Schaeffer, D.J., 1979, Illinois redesigns its ambient water quality monitoring network: Environmental Management, v. 3, no. 4, p. 313-319. [Also available at https://doi.org/10.1007/BF01867438.] 


\section{Appendix 1. Ambient Water Quality Monitoring Network Monitoring Site Information}

Table 1.1. Ambient Water Quality Monitoring Network Monitoring Sites with Illinois Environmental Protection Agency and U.S. Geological Survey identification

[IEPA, Illinois Environmental Protection Agency; ID, identification; USGS, U.S. Geological Survey; --, no data]

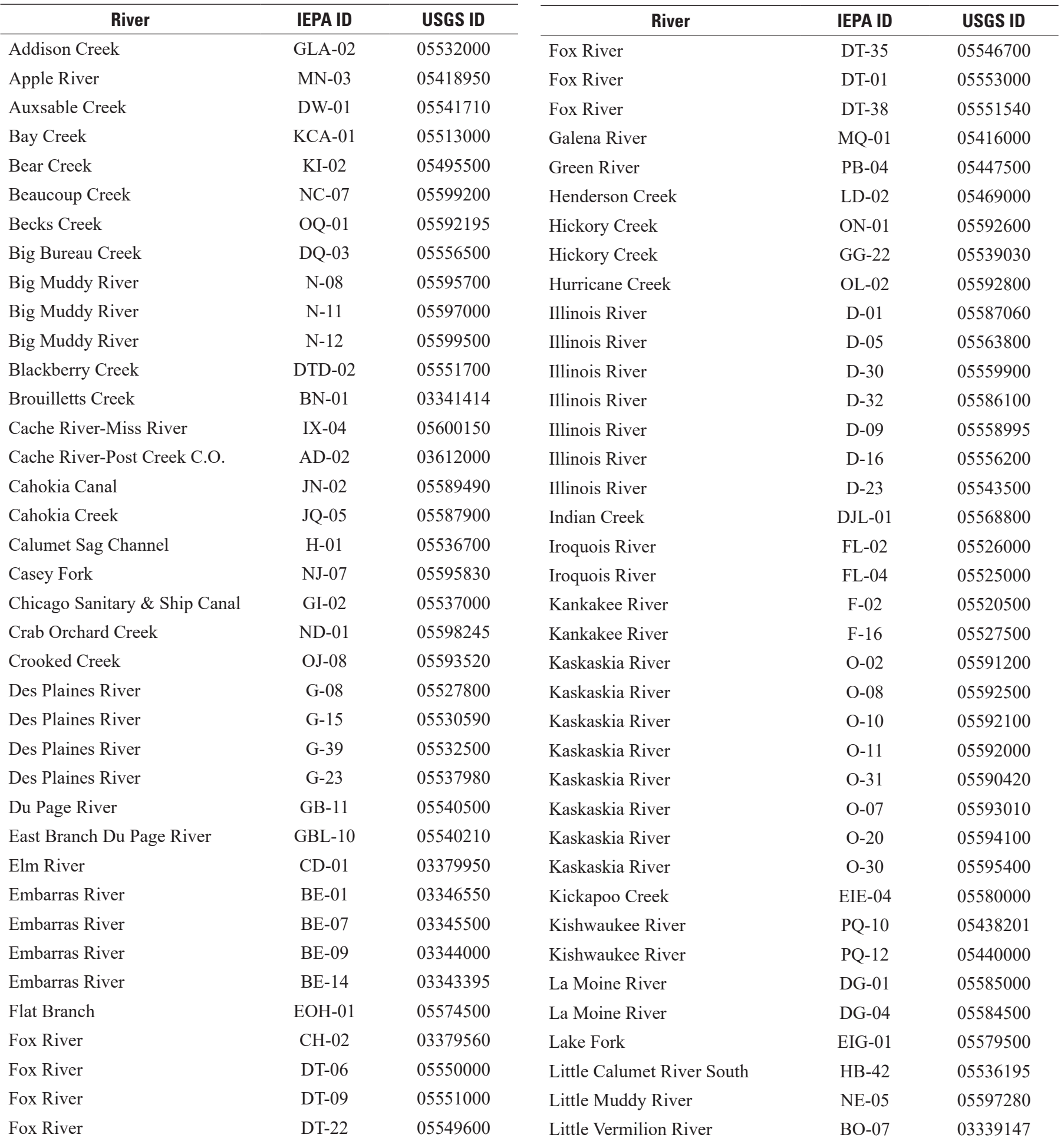


Table 1.1. Ambient Water Quality Monitoring Network Monitoring Sitês with Illinöis Environmentāl Protéction Agency and U.S. Geological Survey identification.-Continued

[IEPA, Illinois Environmental Protection Agency; ID, identification; USGS, U.S. Geological Survey; --, no data]

\begin{tabular}{|c|c|c|c|c|c|}
\hline River & IEPA ID & USGS ID & River & IEPA ID & USGS ID \\
\hline Little Wabash River & C-09 & 03379600 & Rock River & $\mathrm{P}-04$ & 05446500 \\
\hline Little Wabash River & $\mathrm{C}-21$ & 03378635 & Rock River & P-06 & 05443500 \\
\hline Little Wabash River & C-23 & 03381495 & Rock River & P-15 & 05437500 \\
\hline Lusk Creek & AK-02 & 03384450 & Saline Branch & BPJC-06 & 03337700 \\
\hline Macoupin Creek & DA-06 & 05587000 & Salt Creek & EI-02 & 05582000 \\
\hline Marys River & II-03 & 05595540 & Salt Creek & GL-09 & 05531500 \\
\hline Mauvaise Terre Creek & DD-04 & 05586040 & Salt Fork Vermilion River & BPJ-03 & 03338097 \\
\hline Mazon River & DV-04 & 05542000 & Sangamon River & E-25 & 05583000 \\
\hline Mckee Creek & DE-01 & 05585830 & Sangamon River & E-26 & 05576500 \\
\hline Middle Fork Vermilion River & BPK-07 & 03336645 & Shoal Creek & OI-07 & 05593800 \\
\hline Mississippi River & $\mathrm{K}-17$ & -- & Shoal Creek & OI-08 & 05594000 \\
\hline Mississippi River & $\mathrm{K}-21$ & -- & Silver Creek & OD-06 & 05594450 \\
\hline Mississippi River & $\mathrm{K}-22$ & -- & Silver Creek & OD-07 & 05594800 \\
\hline Mississippi River & L-04 & -- & Skillet Fork & CA-05 & 03380500 \\
\hline Mississippi River & $\mathrm{I}-05$ & -- & South Fork Saline River & ATH-05 & 03382100 \\
\hline Mississippi River & $\mathrm{I}-84$ & 07022000 & South Fork Sangamon River & EO-02 & 05575500 \\
\hline Mississippi River & $\mathrm{J}-36$ & -- & Spoon River & DJ-08 & 05570000 \\
\hline North Fork Embarras River & BEF-05 & 03346000 & Thorn Creek & HBD-04 & 05536275 \\
\hline North Fork Saline River & ATF-08 & & Vermilion River & BP-01 & 03339000 \\
\hline North Fork Vermilion River & BPG-09 & 03338780 & Vermilion River & DS-06 & 05554490 \\
\hline Pecatonica River & PW-08 & 05435500 & Vermilion River & DS-07 & 05555300 \\
\hline Poplar Creek & DTG-02 & 05550500 & Wabash River & B-06 & 03341920 \\
\hline Rayse Creek & NK-01 & 05595730 & West Branch Du Page River & GBK-05 & 05540095 \\
\hline Richland Creek-South & OC-04 & 05595200 & West Branch Du Page River & GBK-09 & 05539900 \\
\hline
\end{tabular}




\section{Appendix 2. Supplementary Figures}




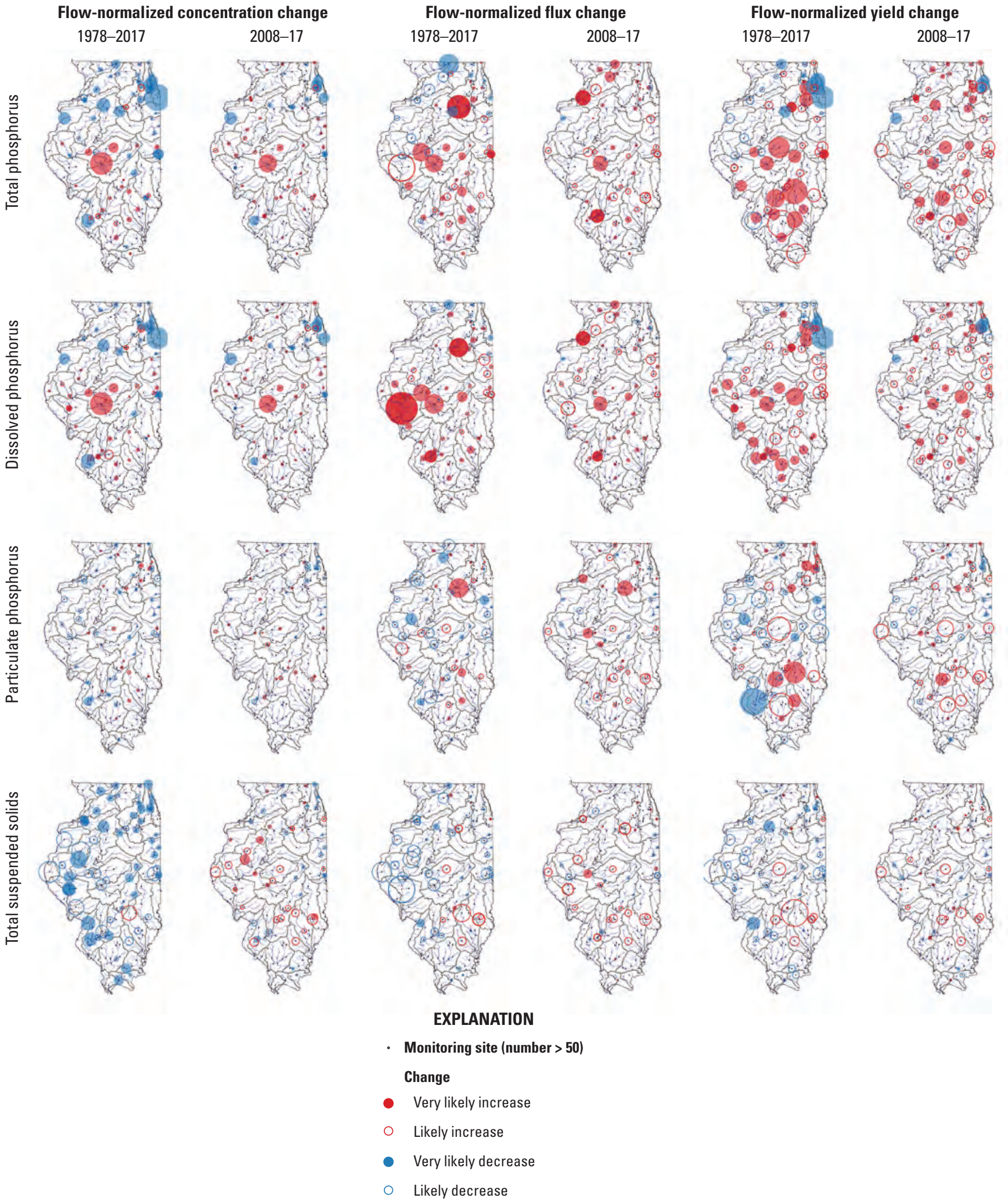

Figure 2.1. Maps of changes in flow-normalized concentration, flux, and yield of total phosphorus, dissolved phosphorus, particulate phosphorus, and total suspended solids. Change direction, magnitude, and likelihood denoted by the color, area, and style of the circle, respectively. Changes in each form of phosphorus are shown using the same scale. 


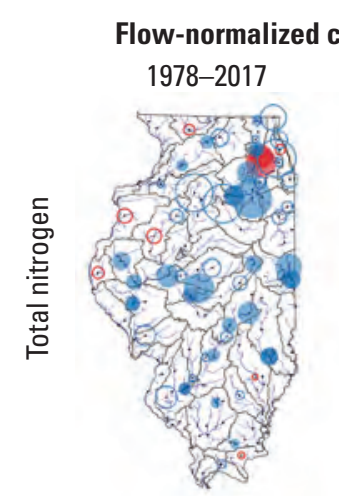

\section{concentration change} 2008-17
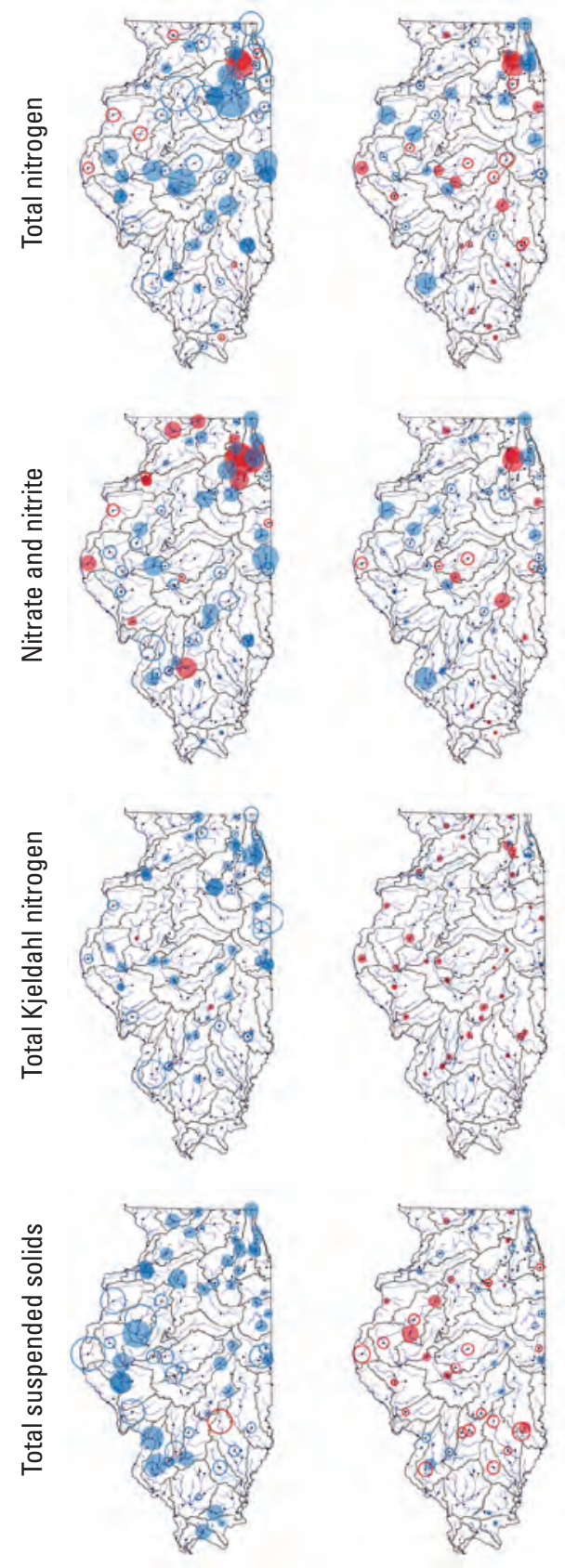

Flow-normalized flux change

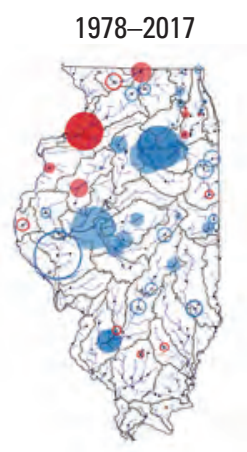

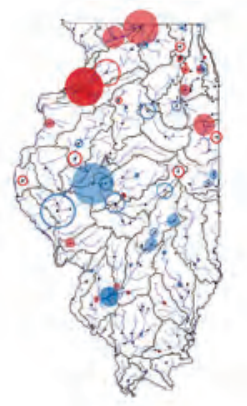
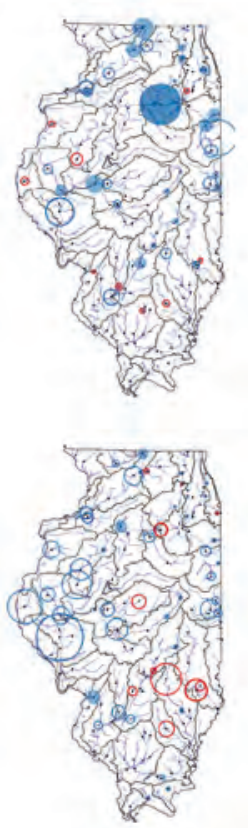
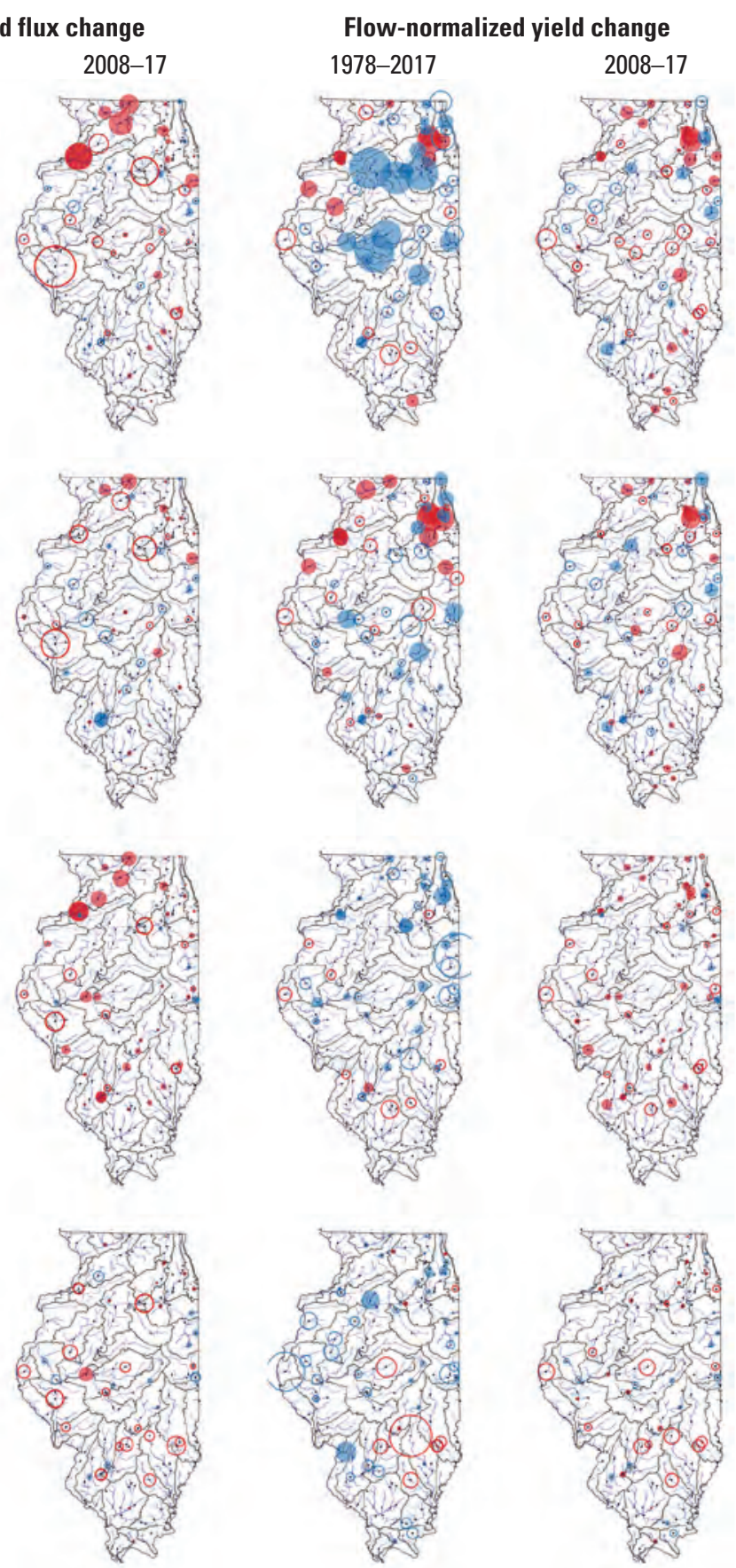

\footnotetext{
- Monitoring site (number $>50$ )

Change

- Very likely increase

- Likely increase

- Very likely decrease

○ Likely decrease
}

Figure 2.2. Maps of changes in flow-normalized concentration, flux, and yield of total nitrogen, nitrate and nitrite, total Kjeldahl nitrogen, and total suspended solids. Change direction, magnitude, and likelihood denoted by the color, area, and style of the circle, respectively. Changes in each form of nitrogen are shown using the same scale. 

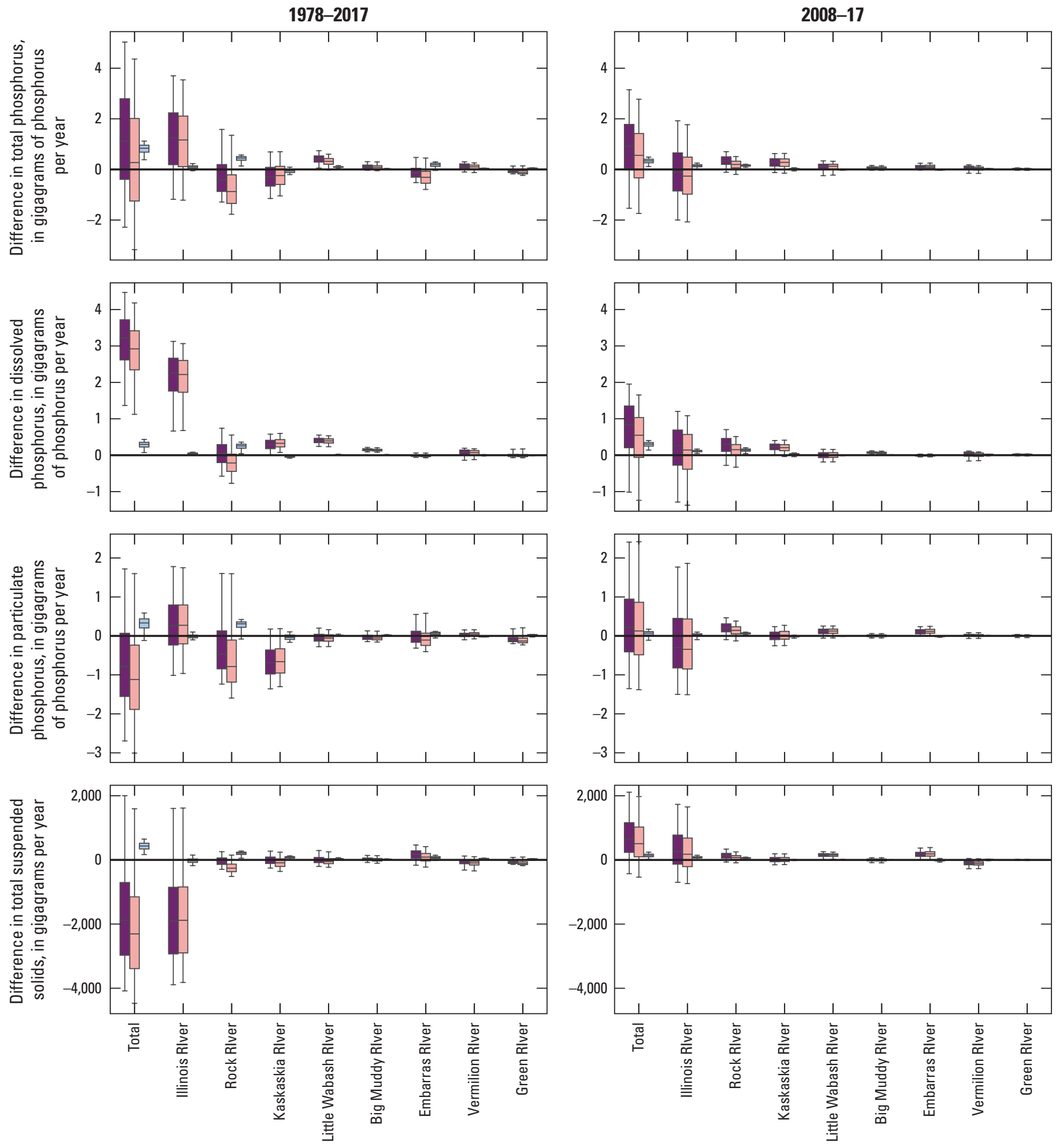

EXPLANATION

Water-quality trend

Concentration-discharge trend component

Streamflow trend component

Figure 2.3. Statewide and major river changes in flow-normalized flux of total phosphorus, dissolved phosphorus, particulate phosphorus, and total suspended solids. 
1978-2017
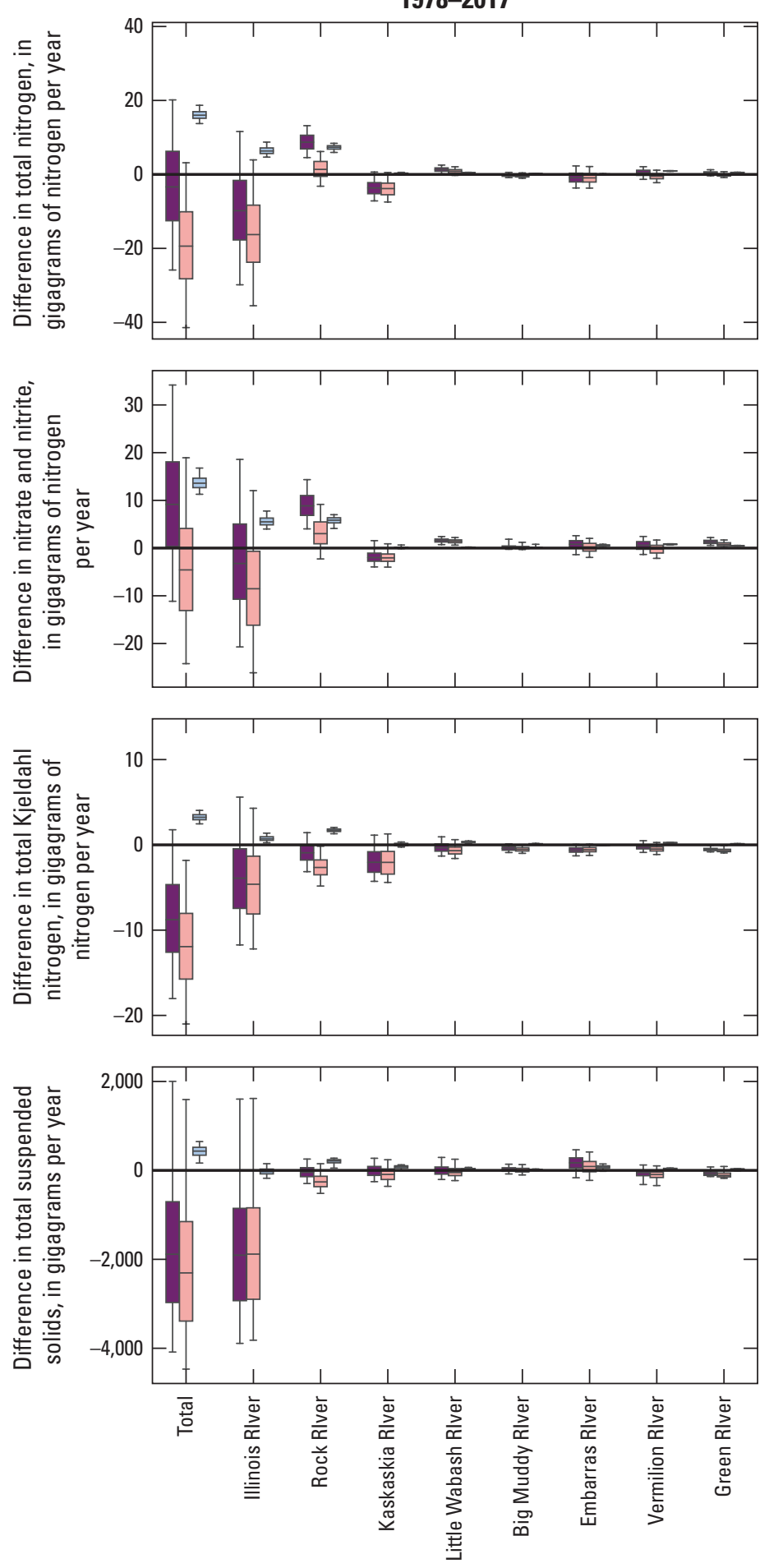

EXPLANATION
2008-17
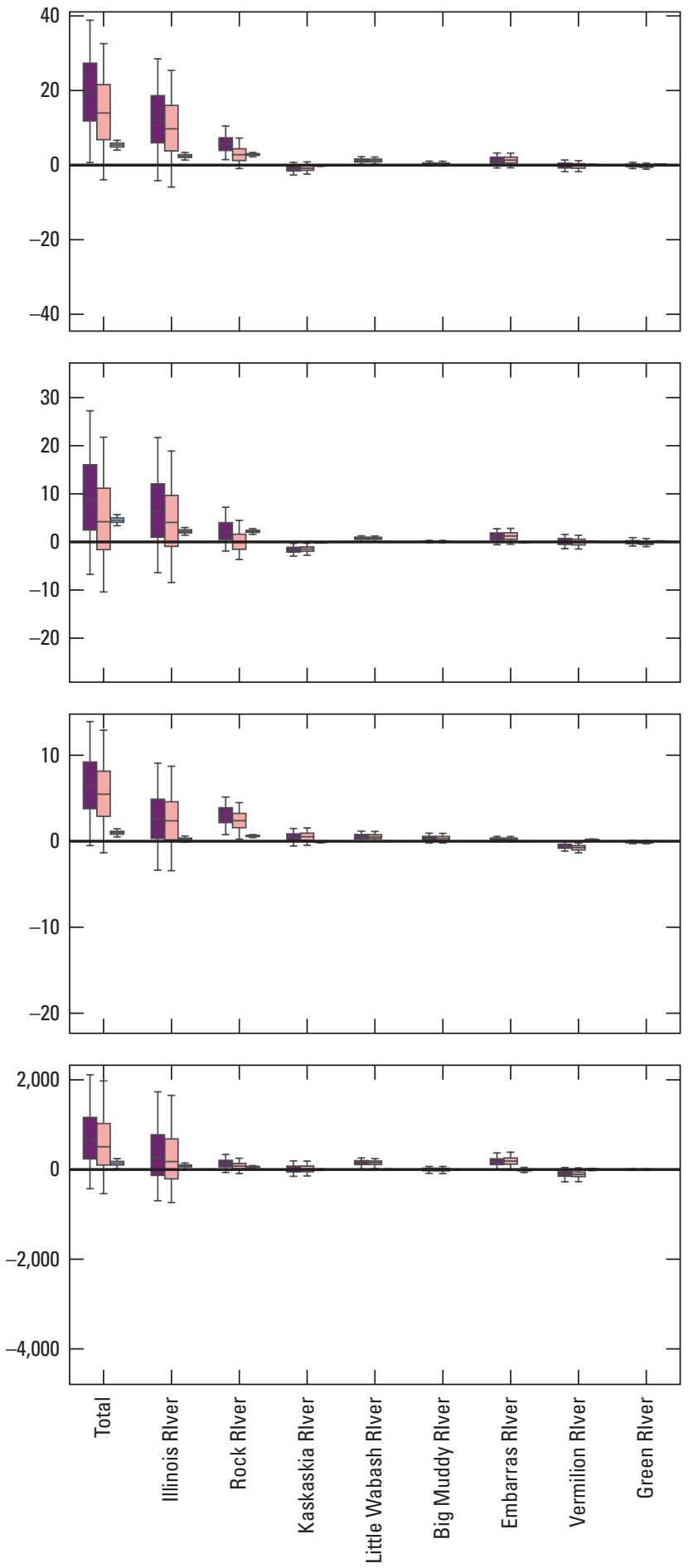

Water-quality trend

Concentration-discharge trend component

Streamflow trend component

Figure 2.4. Statewide and major river changes in flow-normalized flux of total nitrogen, nitrate and nitrite, total Kjeldahl nitrogen, and total suspended solids. 

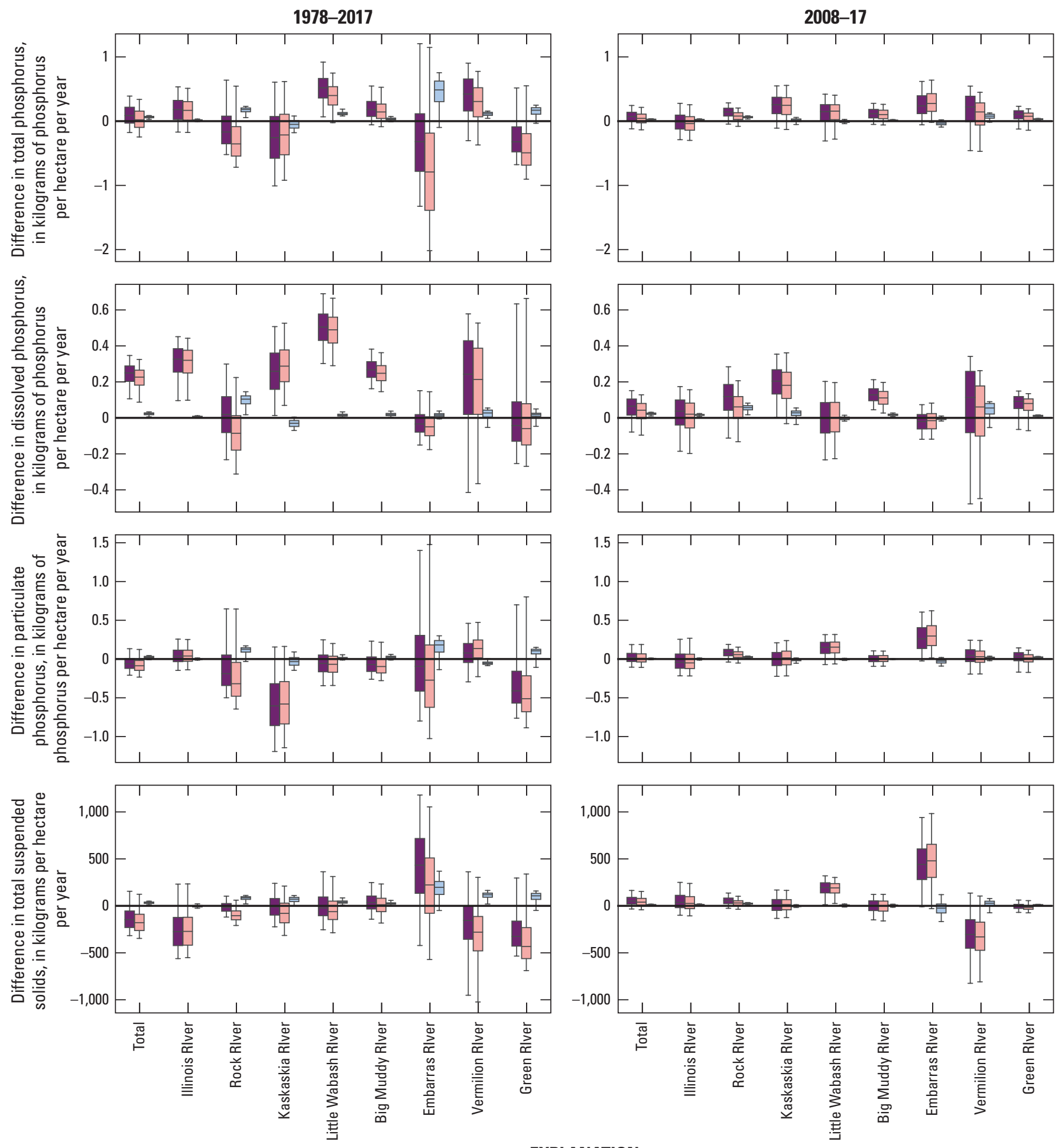

EXPLANATION

Water-quality trend

Concentration-discharge trend component

Streamflow trend component

Figure 2.5. Statewide and major river changes in flow-normalized yield of total phosphorus, dissolved phosphorus, particulate phosphorus, and total suspended solids. 

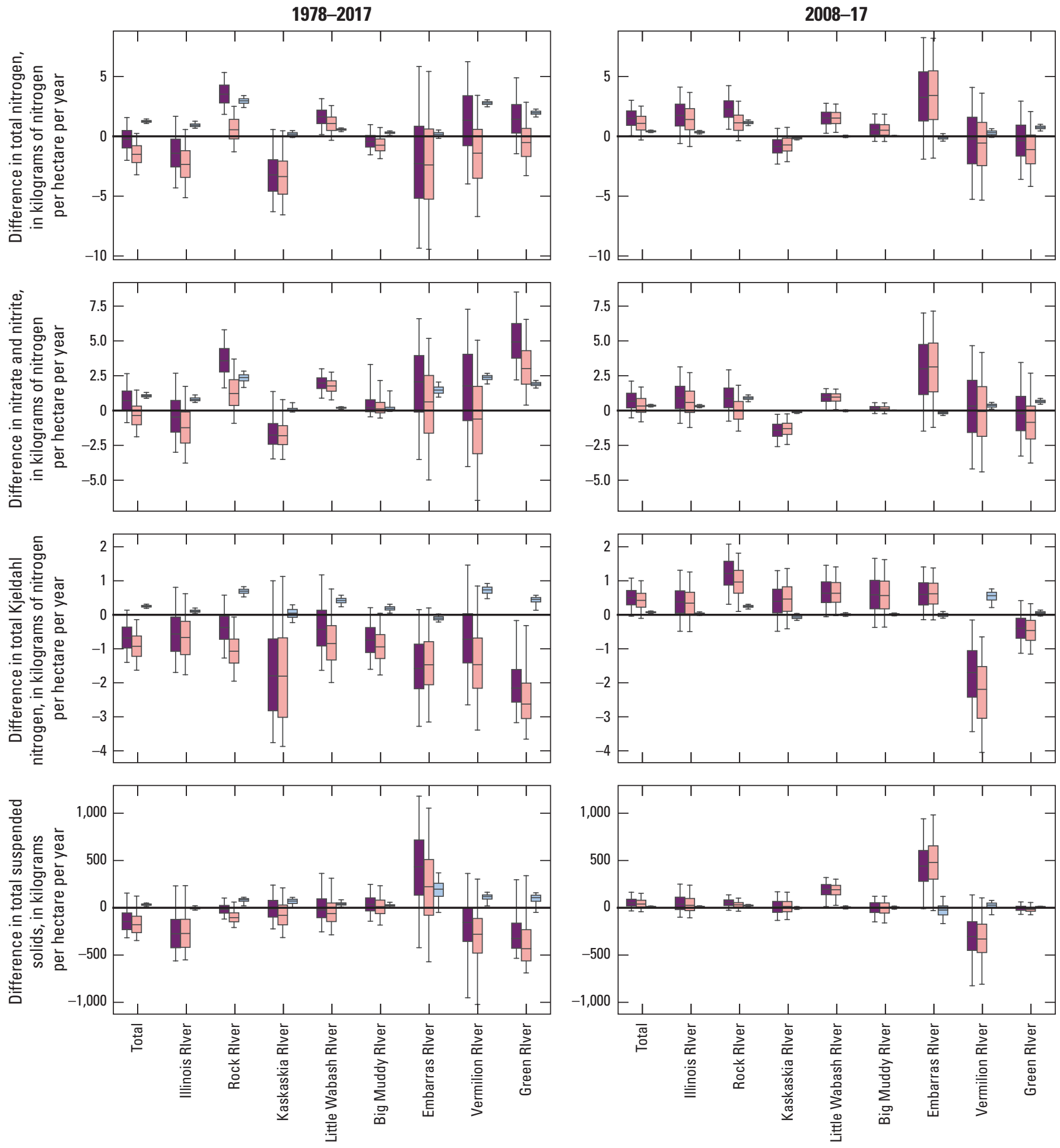

EXPLANATION

Water-quality trend

Concentration-discharge trend component

Streamflow trend component

Figure 2.6. Statewide and major river changes in flow-normalized yield of total nitrogen, nitrate and nitrite, total Kjeldahl nitrogen, and total suspended solids. 

For more information about this publication, contact:

Director, USGS Central Midwest Water Science Center 405 North Goodwin

Urbana, IL 61801

217-328-8747

For additional information, visit: https://www.usgs.gov/centers/cmwater

Publishing support provided by the Rolla and Sacramento Publishing Service Centers 

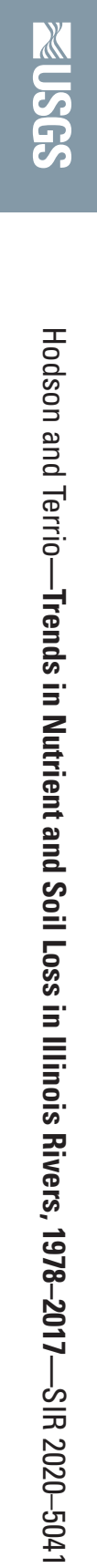